\title{
Russellian Acquaintance Revisited
}

\author{
Ian Proops, The University of Texas at Austin \\ [Pre-publication draft of 8-23-2014, forthcoming in Journal of the History of Philosophy.]
}

\begin{abstract}
In Bertrand Russell's writings during the first two decades of the Twentieth Century there occur two rather different distinctions that involve his much-discussed, technical notion of acquaintance. The first is the distinction between knowledge by acquaintance and knowledge by description; the second, the distinction between knowledge by acquaintance and knowledge of truths. This article examines the nature and philosophical purpose of these two distinctions, while also tracing the evolution of Russell's notion of acquaintance in the first two decades of the twentieth century. It argues that, when he first expressly formulates his Principle of Acquaintance in 1903, Russell's chief concern is to appeal to the first distinction to argue against a certain tightly restrictive epistemology of understanding that he finds in the writings of William James. By contrast, when in 1911 he begins to place emphasis on the second distinction, his concern is to appeal to it in the course of defending his thesis that we are capable of having perfect knowledge (by acquaintance) of particulars. The defense is necessary because this thesis comes under attack from a certain argument Russell finds in the writings of the Monistic Idealists.
\end{abstract}

Introduction

Philosophers sometimes claim that in his 1912 work, The Problems of Philosophy (hereafter cited as $P O P)$, and possibly as early as "On Denoting” (1905), Russell conceives of acquaintance with sensedata as providing an indubitable or certain foundation for empirical knowledge. ${ }^{1}$ However, although 
he does say things suggestive of this view in certain of his 1914 works, Russell also makes remarks in POP that conflict with any Cartesian interpretation of this work. ${ }^{2}$ He says, for example, that all our knowledge of truths "is infected with some degree of doubt, and a theory which ignored this fact would be plainly wrong" (POP, 135). And again: "It is of course possible that all or any of our beliefs may be mistaken, and therefore all ought to be held with at least some slight element of doubt" $(P O P, 25)$. A distinctively Cartesian brand of foundationalism, then, is not what lies behind Russell's interest in acquaintance in $P O P$ or behind the various distinctions in which it figures. But what then does? $?^{3}$

The present article aims to tackle this question by tracing the development of Russell's conceptions of (knowledge by) acquaintance and knowledge by description as they unfold during the years 1900-1918. In particular, I will focus on what Russell sees as being the philosophical significance of two distinctions he draws that involve the notion of (knowledge by) acquaintance. On the one hand, there is:

Distinction $A$ : (Knowledge by) acquaintance versus knowledge by description and, on the other hand, there is:

Distinction B: (Knowledge by) acquaintance versus knowledge of truths (knowledge about). ${ }^{4}$ Although philosophers have sometimes conflated these distinctions, ${ }^{5}$ it is important to keep them sharply distinguished. For they mean different things and-or so I shall argue-differ strikingly in what Russell wants to do with them.

Russell explicitly formulates distinction $A$ for the first time in some study notes from 1903 entitled "Points about Denoting" (hereafter cited as $P A D){ }^{6}$ These notes also contain his first explicit formulation of (some version of) the Principle of Acquaintance (hereafter cited as $P O A)^{7}$ Distinction B, which Russell inherits from William James-who in turn inherits it from Hermann 
von Helmholtz and John Grote-is, by contrast, not formulated with any precision until the spring of 1911, when—or so I shall argue-Russell returned to James's treatment of acquaintance in preparation for writing his article "Knowledge by Acquaintance and Knowledge by Description" (hereafter cited as $K A K D) .{ }^{8}$ Nonetheless, as I shall argue, Russell had a more-or-less firm grip on the distinction from 1903 onward.

Russell deploys distinctions $A$ and $B$ against two rather different targets. He appeals to distinction $A$-and to the thesis that we may know by description certain things with which we lack acquaintance — in the course of challenging the restrictive epistemology of understanding that is—or seems to be-espoused by James in his Principles of Psychology, and which James himself derives—or thinks he derives—from Locke. According to this epistemology, acquaintance—or in James's terminology "sensation" — is both an enabling condition of thought, and hence of knowledge, and the limiting condition of them. ${ }^{9}$ In other words, for James we are able to think about anything with which we are_-or can be_-acquainted, but only about such things.

Russell, I shall argue, seeks to replace James’s epistemology of understanding with a view that resembles it insofar as it treats acquaintance as an enabling condition of thought and knowledge (of truths), but that also differs from it insofar as it denies that acquaintance sets limits to thought, and hence also to knowledge (of truths).

The philosophical use to which Russell puts distinction $B$ is altogether different. In the summer of 1911, in the course of writing POP, he formulates the doctrine that acquaintance with sense-data constitutes knowledge that is "perfect and complete" (POP, 46). He does so, I shall argue, not out of any attachment to a Cartesian version of foundationalism, but rather because he sees this thesis as a way to resist an argument for a certain holistic conception of knowledge that he finds in the writings of the Monistic Idealists.

The present article seeks to develop these points about the philosophical conclusions that 
Russell draws from these two distinctions, while also tracing the development of his conception of acquaintance. It is divided into five sections and a conclusion. The first section examines distinction $A$ in some detail, while the second describes an important change in Russell's conception of acquaintance between the Principles of Mathematics of 1902 and his 1903 manuscripts. I argue that this change is plausibly attributable to Russell's engagement with James. The third section offers an account of the way in which Russell uses distinction $A$ to argue against James's epistemology of understanding. With the fourth section, the paper shifts its focus to distinction $B$. I argue that in 1911 Russell uses this distinction to support the thesis that knowledge by acquaintance is independent of knowledge of truths, and I endeavor to explain why Russell should have taken an interest in this thesis at this time. The fifth section investigates the meaning of Russell's claim that, when we have acquaintance with a sense-datum, we know it "perfectly and completely"; while the sixth examines the way in which Russell puts this thesis to work in opposing a certain argument for the holistic epistemology that is championed by the Monistic Idealists. The seventh section, finally, adjudicates this aspect of Russell's dispute with the Idealists.

1. Distinction $A$ : Knowledge by Acquaintance versus Knowledge by Description

Russell's very first explicit outline of the contrast between knowledge by acquaintance and knowledge by description occurs in some study notes from 1903 entitled "Points about Denoting" (hereafter cited as $P A D)$. In the opening sentence of these notes, Russell observes that sometimes "we know that something is denoted, without knowing what" (Papers, 4:306). We might—-to amend Russell's own obviously imperfect example_know that Smith's spouse ${ }^{10}$ exists even if we fail to be acquainted with the person in question. This will be possible so long as we know, first, that Smith is 
married, and, second, that every married person has a unique spouse (306). ${ }^{11}$ Russell concludes that "To be known by description is not the same thing as to be known by acquaintance" (306). Since $P A D$ belongs to a phase of Russell's career in which he still treats denoting phrases as expressing denoting concepts, the doctrine of knowledge by description thus predates the theory of descriptions.

But, although by 1903 Russell is clear in his own mind about distinction $A$, he does not attempt to formulate this distinction with any precision until some eight years later. In his article "Knowledge by Acquaintance and Knowledge by Description" (hereafter cited as $K A K D$ ), he characterizes knowledge by acquaintance in a way that amounts to the following:

$S$ knows $x$ by acquaintance just in case $S$ stands in a direct cognitive relation to $x$, namely, the converse of the relation of presentation. ${ }^{12}$

In POP, which Russell composed a few months later, ${ }^{13}$ he says, more simply, that we have acquaintance with "anything of which we are directly aware, without the intermediary of any process of inference or any knowledge of truths" (POP, 46-47). He appears to mean that we have acquaintance with all and only such things.

In $K A K D$ Russell's characterization of knowledge by description is less precise than his characterization of knowledge by acquaintance. It runs: "I shall say that an object is 'known by description' when we know that it is 'the so-and-so', i.e., when we know that there is one object, and no more, having a certain property" (Papers, 6:151). We might attempt to make this more precise in the following way: 
$<\operatorname{ext}>S$ knows $x$ by description just in case for some property $F, x=$ the $F$ and $S$ knows that there is exactly one $F^{14}$

$</$ ext $>$

However, we should keep in mind that Russell would not himself wish to state the idea quite so straightforwardly; for this formulation contains a quantifier - 'for some property, $F$ - that purports to straddle logical types. It is perhaps for this reason that he tends to rely on examples—rather than precise formulations - when trying to get the distinction across.

In $K A K D$ Russell says that when an object is said to be "known by description" by a subject, $S$, it will generally be "implied" that $S$ does not know it by acquaintance (Papers, 6:151). Since in the very next paragraph he allows that a subject may know a thing both by acquaintance and by description, the word "implied" cannot be intended to express a relation of entailment. Instead, it seems to be intended to express something closely akin to Grice’s “implicated.” Russell's point (as we might put it today) is that, when one assertively utters "such-and-such is known by description," one conveys or communicates that such-and-such is not known by acquaintance, where what is conveyed is no part of what is thereby said.

In $K A K D$, immediately after presenting distinction $A$, Russell proceeds to characterize a notion of merely descriptive knowledge. "We have," he says:

$<$ ext>'merely descriptive knowledge' of the so-and-so when, although we know that the soand-so exists, and although we may possibly be acquainted with the object which is, in fact, the so-and-so, yet we do not know any proposition [of the form] ' $a$ is the so-and-so', where $a$ 
is something with which we are acquainted. (Papers, 6:151)

$</$ ext $>$

More precisely: A subject, $S$, has merely descriptive knowledge of the-so-and-so just in case $S$ knows that the so-and-so exists but knows no proposition of the form " $a$ is the so-and-so," where " $a$ " is a genuine Russellian name. ${ }^{15}$ Since in KAKD Russell equates "knowing which thing something is" with knowing the truth expressed by a sentence of the form ' $a$ is the so-and-so,' we can say on his behalf — and using his terminology — that someone who has merely descriptive knowledge of a thing knows it by description without knowing which thing it is (The problems for Russell's treatment of "knowing which" are not few, but I will not discuss them here). ${ }^{16}$

Russell's characterization of merely descriptive knowledge reveals that he does not at this stage take acquaintance to entail knowledge which. For if he did, he could not grant — as he in fact does ${ }^{17}$ - that someone who had merely descriptive knowledge of a thing, and who was therefore (in his terminology) ignorant of which thing it was, might nonetheless happen to be acquainted with it. This feature of Russell's view has a perhaps unexpected consequence: it means that in $K A K D$ Russell must be implicitly distinguishing between knowledge which and knowledge what. For in this same article he equates knowledge what with acquaintance_-as the following passage makes clear:

$<$ ext $>$ Whenever a relation of supposing or judging occurs, the terms to which the supposing or judging mind is related by the relation of supposing or judging must be terms with which the mind in question is acquainted. This is merely to say that we cannot make a judgment or supposition without knowing what it is that we are making our judgment about. (Papers, 6:155; emphasis in the original) $</$ ext $>$ 
In order for the gloss on the $P O A$ in the second sentence of this passage "merely to say" what is said by the first, Russell must be equating the notion of knowing what it is one is judging about with that of being acquainted with the objects of one's judgment. ${ }^{18}$

This equation might sound unnatural, and it could certainly be challenged on grounds stemming from linguistic theory; so it is worth noting one route by which Russell might have arrived at it. ${ }^{19}$ I shall argue that Russell's discussion of acquaintance is plausibly indebted to James's work, The Principles of Psychology. ${ }^{20}$ If Russell had seen a popular abridgment of that work, Psychology (1892), he might have encountered the following remark: "Our earliest thoughts are almost exclusively sensational. ${ }^{21}$ They give us a set of whats, or thats, or its; of subjects of discourse in other words, with their relations not yet brought out" (14). (Mention of "whats" is absent from the corresponding passage in the unabridged version, which speaks only of "thats" and "its.") Since James equates acquaintance with knowledge by means of sensations, we may take him to be maintaining that the knowledge we have in acquaintance is knowledge of those whats that we are thinking about in our "sensational" thoughts. ${ }^{22}$ A similarly idiosyncratic use of the word "what" appears in James's article "On the Function of Cognition" (1885), where James says: "Now, our supposed little feeling gives a what; and if other feelings should succeed which remember the first, its what may stand as subject or predicate of some piece of knowledge-about, of some judgment, perceiving relations between it and other whats, which the other feelings may know" (32). If Russell had been familiar with either of these passages — or with similar passages in James's writings — he could easily have made the slide from the awkward phrase "knowledge of a what that we are thinking about" to the more natural "knowledge of what we are thinking about." At any rate, the hypothesis of such a slide would explain his otherwise puzzling equation of acquaintance with knowledge what. ${ }^{23}$

Such an equation, in addition to being puzzling on its face, might also appear to sit awkwardly with Russell's doctrine that we know by description many things with which we lack 
acquaintance. For, with the equation in place, Russell's gloss on the $P O A$ in the passage from $K A K D$ just quoted would seem to entail a denial of that doctrine. Fortunately, however, the difficulty arises only because in $K A K D$ Russell equivocates on the term 'about.' Although he sometimes writes as though I can be said to have made a judgment about something merely by dint of asserting a sentence containing a definite description denoting that thing, at other times, he maintains that I can be said to have made a judgment about a thing only if the thing occurs as a constituent of the judgmental complex I form in making the judgment. In $K A K D$ the word 'about' occurs in these two different senses in the space of a single remark:

$<$ ext $>$ It would seem that, when we make a statement about something only known by description, we often intend to make our statement, not in the form involving the description, but about the actual thing described. (Papers, 6:153)

$</$ ext $>$

Since this remark occurs just two pages before Russell's formulation of the $P O A$ in $K A K D$, we can resolve our difficulty simply by supposing that in his gloss on that formulation Russell is using the word 'about' in the second, stricter way. In other words, he is claiming that when I make a judgment - for example, the judgment that $a \mathrm{R} b$, where " $a$," "R," and " $b$ " are genuine Russellian names-I must be acquainted with such constituents of the judgmental complex as he would previously (that is, when he still believed in propositions) have regarded as the constituents of the proposition judged - in our case, $a, \mathrm{R}$, and $b$. He is not claiming that I cannot make judgments about objects with which I am not acquainted, for definite descriptions enable me to do just that—or, rather, they do so as long as I am acquainted with the meanings of their constituents. 
2. The Genesis of the Principle of Acquaintance

In this section I will try to explain why Russell does not formulate the $P O A$ until 1903 —or rather, since I believe that something closely akin to the principle is already in place before 1903, I will try to explain why he does not formulate this principle in the way he does in $P A D$ - that is, in terms of acquaintance-until this date. Let us begin by asking why the $P O A$ occurs neither in the Principles of Mathematics itself nor in any other of Russell's writings that overlap the period of composition of this work.

We can usefully focus our discussion by considering an account of the absence of any statement of the $P O A$ in the Principles that has been suggested by Peter Hylton in his book, Russell, Idealism, and the Emergence of Analytic Philosophy. In Hylton's opinion, there is no reason for Russell to formulate the $P O A$ in the Principles simply because:

$<$ ext $>$ at this stage in his work it imposes no constraints and is thus quite trivial. The one exception to this is the case of propositions about the infinite, for Russell denies that we are acquainted with any such propositions. How, then, can we understand and know propositions about the infinite? Russell's answer is that what we understand in each such case is a finitely complex proposition, one of whose constituents denotes infinitely many terms. (Hylton, Russell, Idealism, and the Emergence of Analytic Philosophy, 246). $</$ ext $>$

In Hylton's view, the Principles contains no formulation of the $P O A$ simply because this principle is too trivial to warrant the fanfare of an explicit formulation. Its triviality is owed to the fact that it imposes no constraints, or - at any rate- very few of them. 
I find this explanation somewhat unpersuasive. I do so simply in view of the sheer importance of the one exception Hylton acknowledges to his claim that the principle imposes no constraints. Propositions about the infinite, after all, lie at the heart of mathematics. If the constraint imposed by the $P O A$ is operative in shaping Russell's analysis of those propositions, then the principle is surely substantive enough to rob Hylton's "triviality" claim of all plausibility. Indeed, if Hylton is right, the $P O A$ motivates one of the deepest features of Russell's philosophy of logic in the Principles, namely, his view that the generality of propositions is to be explained in terms of their containing denoting concepts.

Nonetheless, Hylton is surely right to suggest that some principle akin to the $P O A$ is implicitly at work in constraining Russell's analyses of propositions in the Principles. So the question naturally arises whether this principle is, as Hylton supposes, the $P O A$ itself or whether it is some other, perhaps closely related, principle. I am inclined to favor the latter answer and in the remainder of this section I will try to explain why.

First, we should note a point made by James Levine: it turns out that Russell formulates a principle very like the $P O A$ in a paper he presented to the Oxford Philosophical Society in May $1900 .^{24}$ There he says:

$<$ ext $>$ Everything that can occur in a proposition must be something more than a mere idea - it must be the object of an idea, i.e. an entity to which an idea is related .... Whatever can form part of a judgment which we make must be the object of one of our ideas. ("Is Position in Time Absolute or Relative?” Papers 3:229) $</$ ext $>$

For convenience I will refer to the principle apparently propounded in the second sentence of this passage as the "Ideas Principle." 
I think that by drawing attention to the Ideas Principle Levine has identified a principle plausibly at work in the Principles constraining Russell's account of propositional structure. My only small point of disagreement with him is about whether in the Principles Russell yet had the kind of conception of acquaintance that could have enabled him to think of the Ideas Principle as a principle specifically of acquaintance. I wonder about this because I do not see that in the Principles Russell could yet have understood the notion of having an idea of an object as consisting in —or even as entailing - the notion of having acquaintance with that object. For such a construal would, I believe, conflict with what Russell has to say in the preface to the Principles about the ultimate goal of philosophical logic. He says:

$<$ ext $>$ The discussion of indefinables_- which forms the chief part of philosophical logic — is the endeavour to see clearly, and to make others see clearly, the entities concerned, in order that the mind may have that kind of acquaintance with them which it has with redness or the taste of a pineapple. Where, as in the present case, the indefinables are obtained primarily as the necessary residue in a process of analysis, it is often easier to know that there must be such entities than actually to perceive them; there is a process analogous to that which resulted in the discovery of Neptune, with the difference that the final stage- the search with a mental telescope for the entity which has been inferred-is often the most difficult part of the undertaking. (preface $x v)$.

$</$ ext $>$

This passage, which contains the only occurrence of the word 'acquaintance' as a term of art in the entire Principles, makes clear that the result of getting oneself to "see clearly the entities concerned" (whatever that comes to) is supposed to be that one comes to have the kind of acquaintance with them that one has with redness or the taste of a pineapple, namely-one presumes-immediate or 
direct acquaintance. ${ }^{25}$ But on the assumption that the $P O A$ is already in place in the Principles, it is hard to see how philosophical logic could have quite this as its ultimate goal. For that principle entails that a subject must already enjoy immediate acquaintance with the indefinable constituents of any proposition she understands merely by dint of understanding that proposition in its unanalyzed form.

If philosophical logic is to do any real work, then, the $P O A$ cannot yet be in place in the Principles_or, at least, it cannot be in place while incorporating the notion of acquaintance under discussion in the preface. To put the point somewhat differently, it seems that 'acquaintance,' as Russell uses the term in the preface, must signify a notion richer than the one signified by this term as it occurs in the 1903 formulation of the $P O A$ - the latter occurrences expressing merely the notion of having an idea of (or being presented with) an object.

There is, moreover, a second route to this same conclusion. If the fruits of philosophical logic are to be informative or interesting, it seems that, when one achieves acquaintance with an indefinable, one must thereby attain knowledge of which thing that indefinable is, as well, perhapsthough this is less clear-as knowledge of how its presence in a proposition contributes to the determination of that proposition's truth-conditions. ${ }^{26}$ When the goal of philosophical logic is attained, I come to know, for example, that among the indefinables are denoting concepts: entities that play a certain distinctive "aboutness shifting" role in propositions. ${ }^{27}$ But the knowledge of which things are the indefinables is knowledge that Russell would later come to categorize as "knowledge about" the entities in question, and hence, by distinction $B$, it is something that goes beyond what is yielded by acquaintance on Russell's later understanding of 'acquaintance.' If distinction $B$ is already in place in 1903, then — and I shall argue that plausibly it is-we must conclude that when Russell first states the $P O A$ in $P A D$, the notion of 'acquaintance' that figures in the principle must be a considerably leaner notion than it was in the Principles. 
I conclude that if the Ideas Principle is - as it seems to be-at work in the Principles shaping Russell's various analyses, he would not yet have thought of it as a principle of acquaintance. But if the idea of having an idea of an object that figures in the Ideas Principle cannot be glossed in terms of Russell's 1902 notion of acquaintance, how should it be glossed? To answer this question we need to consider how he appeals to the Ideas Principle in practice. One application of this principle is stated in a draft of the Principles from 1899-1900. Russell says:

$<$ ext $>$ [The difficulty of giving an account of the meaning of phrases of the form "all Fs"] does not arise as regards classes which have a finite number of terms. "All men are mortal" may be interpreted as a compendious formula for "A. B., and N. M., and Z. Q. are mortal." But can we apply this to "all numbers are odd or even"? Here we cannot mention them all, and there are innumerable numbers we have never thought of (1899-1900 draft of the Principles, Papers, 3: 43). $</$ ext $>$

Here, we see the Ideas Principle at work imposing precisely the kind of constraint envisaged by Hylton - a constraint on the constituent structure of propositions about infinite collections. Russell seems to be making the following assumption: we could not be supposed to have an idea of an object that occurs in a proposition's subject position if we could not mention it. One supposes that this is an instance of the more general assumption that one could not have an idea of a propositional constituent if one could not "indicate" it. For indication is the general relation of which mentioning is a species. At this stage, to a first approximation one mentions those propositional constituents that the proposition can be said to be "about," and one merely indicates the others.

It is important to realize that there is another respect in which 'mention' functions a technical term for Russell. I mention something only when I designate it with a genuine name- 
something that Russell, at this stage, calls a 'proper name'-and which commentators often refer to as a 'logically proper name,' though I know of nowhere that Russell uses that expression. ${ }^{28}$ In particular, as the following remark shows, I do not mention an object when I designate it using a definite description:

$<$ ext $>$ Often two denoting concepts occur, and the term itself is not mentioned, as in the proposition 'the present Pope is the last survivor of his generation'. (Principles, \$64) $</$ ext $>$

Russell means that the denoted object, Pope Leo XIII, is not mentioned by name in this identity statement. Accordingly, in the draft of the Principles of 1899-1900 Russell is not operating on the assumption that in order to apprehend a proposition we must be able to indicate or denote each of its constituents. His point is rather that we must stand in a more direct relation to them- one of being able to refer to them by means of a genuine Russellian name.

All of this suggests three important points. First, in the Principles—or at least at the time of the draft of 1899-1900-Russell is interpreting the notion of having an idea of an object as it occurs in the Ideas Principle in such a way that I can be said to have an idea of an object only if I am in a position to mention it (or, when it is a "verb" or "adjective," indicate it). Second, at this stage, one's being in a position to denote the object in question is not envisaged as a way of "having an idea of an object." Third, at this stage, the notion of having an idea of an object is not explained in terms of acquaintance.

By 1903 Russell's views have undergone a shift. For he is now for the first time prepared to use the concept of acquaintance to express the notion of having an idea of an object. His view is now that a subject $S$ has an idea of an object $x$ just in case $S$ stands in a relation of immediate acquaintance with $x$. However, the notion of immediate acquaintance is not at this stage quite what one 
would expect. For, as we shall see, in spite of being termed "immediate," it tolerates a certain kind of mediation.

Russell's coming to use the term 'acquaintance' to express the notion of having an idea of an object is, I would suggest, a consequence of precisely the thinning-out of the notion of acquaintance that we have just noted. To have immediate acquaintance with an object now no longer requires that one have knowledge of which constituent it is_-or, indeed, knowledge of any other truth. It merely requires the kind of mental contact implied by the most minimal understanding of "having an idea of the object."

A further complication is that at this point Russell attempts to gloss the notion of an idea's being “of" an object in terms of its bearing a semantic_or quasi-semantic_relation to the object in question. Thus, for example, in his 1903 study notes “On Meaning and Denotation,” he says:

$<$ ext $>$ It is true that we have no proper name for (say) the resemblance of yellow and green; nevertheless we must have that kind of immediate acquaintance with it which consists in having an idea designating it. (OMD, 324; emphasis added) $</$ ext $>$

Ideas in this context are avowedly psychological (Papers, 4:320-21); so here immediate acquaintance is being treated as a relation that holds between a subject and an object in virtue of that subject's entertaining an idea that bears the quasi-semantic relation of "designating" to the object in question. ${ }^{29}$ One presumes that the relation qualifies as "immediate" because, although it is mediated by psychological and quasi-semantic relations (such as designating and expressing), it is not mediated by any logical relation, and, in particular, it is not mediated by the relation of denoting. We can be sure 
that in this context 'designate' does not mean 'denote' because in this same paper Russell contrasts expressions that 'designate' with those that 'describe,' and thus with those that express concepts that denote their associated objects (Papers 4:315).

It is this psychologically and quasi-semantically mediated notion of "immediate acquaintance" that figures_or so I would claim—simply as "acquaintance" in Russell's formulation of the $P O A$ in his study notes from the same year, $P A D$. This principle now runs:

$<$ ext $>$ It is necessary for the understanding of a proposition, to have acquaintance with the meaning of every constituent of the meaning, and [with the meaning] of the whole. (Papers, $4: 307)$

$</$ ext $>$

The principle is stated in this somewhat unfamiliar form because at this stage Russell takes it that propositions have both meanings and denotations. When he says that we must have acquaintance with the meaning of every constituent "of the meaning" he just means that we must have acquaintance with the propositional constituents themselves rather than with what they denote.

The notion of acquaintance as it figures here is now considerably thinner than it was in the preface to the Principles. I do not advance the work of philosophical logic merely by having acquaintance with the constituents of the propositions that I grasp. For an understanding of which things the constituents are, or of how they contribute to the proposition's truth conditions, is not contained in the kind of acquaintance necessary for grasping a proposition. Notice that nonetheless, since acquaintance in 1903 is treated as a matter of having an idea of an object, the $P O A$ is just what the Ideas Principle becomes when this new, thinner notion of acquaintance is substituted for the notion of having an idea of an object that occurs in the Ideas Principle. What changes between 1902 and 1903, then, is not so much the meaning of the Ideas Principle as the meaning of 'acquaintance.' In 
1903 acquaintance is both a thinner notion than in 1902 and also one that - in spite of being termed "immediate"—is avowedly psychologically and semantically mediated.

What prompts these developments in Russell's philosophy? This is not altogether clear, but I think a case can be made that they may have been prompted by his having returned at this time to the treatment of acquaintance one finds in James. The hypothesis of such a return is supported by a conspicuous accumulation in Russell's writings during the lull between the Principles and OD of terminology from James's discussion of acquaintance. In $P A D$, for example, Russell speaks—to my knowledge for the first time_-of something's being "known by acquaintance." He thereby echoes James's talk of "knowledge-of-acquaintance" in the Principles of Psychology. And, as we have seen, in OMD he speaks_-again, so far as I know, for the first time_-of our having "immediate acquaintance" with certain relations, thereby employing a phrase that occurs both in the abridged version of the Principles of Psychology [Psychology 1892] and in James's 1895 article "The Knowing of Things Together" (109). Finally, in “On Denoting”- - again, apparently for the first time-Russell presents a distinction between acquaintance and knowledge about, thereby contrasting two terms that are saliently contrasted by James in the Principles of Psychology (1:221).

External evidence for a more intense engagement with James at this time is harder to come by. But we can at least glean from Russell's correspondence that a return to James's views on acquaintance might have been prompted by his having read, in the Autumn of 1902, James's work, The Varieties of Religious Experience. ${ }^{30}$ At any rate, the case for such a return seems to be sufficiently strong to warrant its assumption as a working hypothesis.

The more specific hypothesis that Russell picked up his 1903 use of 'acquaintance' from James would serve to explain two features of his new conception of acquaintance. First, as we have seen, Russell countenances the idea that 'immediate' acquaintance might be compatible with psychological mediation; for he holds that one's having acquaintance with a thing consists in one's 
having an idea of it. This feature of his view might be explained as an idea Russell simply took over from James. For in the first volume of the Principles of Psychology James writes: "What we are only acquainted with is only present to our minds; we have it, or the idea of it" (Psychology vol. 1, 222). Clearly, in James's view the directness of the relation of acquaintance-a directness signified by the word 'present' - is not undermined by the thought that a subject's having acquaintance with an object might be a matter of that subject's having an idea of that object. Second, as we have noted, there is a certain thinning in Russell's notion of acquaintance. By 1903 acquaintance is no longer thought of as bringing with it knowledge of which thing one is acquainted with. This feature of Russell's view might be explained by the influence of James's insistence in the Principles of Psychology on what we have called distinction $B(1: 221)$. For, as we have noted, knowledge which, for Russell, is expressly propositional, and so, by distinction $B$, cannot be part of knowledge by acquaintance.

By $O D$ there is no longer any suggestion that acquaintance may be mediated by psychological and semantic relations. One wonders whether G. E. Moore's insistence, in his 1903 article "The Refutation of Idealism," that our awareness of objects of all kinds is (in every sense) direct awareness might have played a role in shaping this aspect of Russell's view. ${ }^{31}$ But the point on which I wish to place the most emphasis is that there is an evolution in Russell's use of the word 'acquaintance' between the Principles and his 1903 manuscripts. Because the word shifts its meaning it would be misleading to say that the $P O A$ was already in place in the Principles. At that stage Russell simply lacked the right conception of acquaintance to frame the Ideas Principle as a principle of acquaintance. What is true-and here I agree with both Hylton and Levine-is that in the Principles Russell was plausibly operating with a principle that had the same significance as the principle that in 1903 Russell presents as the $P O A$, but which in 1902 was not yet formulated using the word 'acquaintance.' The second point I want to emphasize is that the shift in Russell's use of 'acquaintance' is plausibly the result of his 1903 engagement with James. 
A by-product of the return to James, I would argue, is that Russell comes to see something important about the epistemological role of denoting. He comes to see that the notion can help him to resist a certain kind of restrictive epistemology of understanding that is suggested in James's writings. It is to this issue that I now turn.

3. Russell against James on the Epistemology of Understanding

In $O D$ Russell places considerable weight on the idea that denoting, in addition to playing important logical and mathematical roles, also plays a distinctively epistemological role insofar as it enables us to know of the existence (and features) of particulars with which we are not acquainted $(O D, 415)$. A paradigm case of this phenomenon—one that Russell already recognized in 1903 — is our knowledge of the existence and features of the center of mass of the solar system at some definite point in time (PAD, Papers, 4:306; OD, Papers, 4:415). In Russell's view, we lack acquaintance with this object simply because we lack acquaintance with any spatial point or temporal instant (compare OMD, Papers, 3:323-24). And yet, since we know on theoretical grounds that any material body has a center of mass, we can know that this point exists (so long as we know that the solar system is an existing material body).

The distinctively epistemological role that Russell recognizes for denoting in $O D$ would seem to be conceived of as extending beyond the role that he had assigned to it in the Principles, namely, that of enabling us to have thoughts and knowledge about infinite collections or pluralities. For that role, even if it is partly epistemological, is also plainly logical or mathematical in nature. Indeed, in the Principles Russell expressly characterizes "the logical purpose" of denoting as being to enable propositions of finite complexity to "deal with" infinite classes of terms $(\$ 141)$. What, then, 
accounts for the emphasis Russell places in $O D$ —indeed, on the first page of that work—on the theme that denoting plays the nonlogical and nonmathematical, but epistemological, role of enabling us to have thoughts about particulars with which we are not acquainted?

One plausible hypothesis, I would argue, is that Russell sees the very existence of knowledge by description as demonstrating the need to modify a view of the "boundaries of thought" that occurs in the writings of James and of James's Locke. ${ }^{32}$ Russell, as I read him, sympathizes with the spirit of this view, but he also regards it as guilty of overshooting in a certain way. In consequence, he sees it as standing in need of a rather drastic modification.

If Russell had returned to James’s writings on acquaintance in or around 1903, he would have been greeted in the second part of the Principles of Psychology with a strikingly bold epistemological thesis. "Sensations," says James, "first make us acquainted with innumerable things, and then are replaced by thoughts which know the same things in altogether other ways." ${ }^{33} \mathrm{~A}$ few pages earlier he had said, more strongly: "We can only think or talk about the relations of objects with which we have acquaintance already" (first emphasis added). ${ }^{34}$ For James, then-at least in these passages — we can never have thoughts about (or, consequently, have knowledge about) things with which we are not (and will never be) acquainted.

In propounding this doctrine James takes himself to be following Locke, from whom he quotes the following remark with unqualified approval:

$<$ ext $>$ The simple ideas we receive from sensation and reflection are the boundaries of our thoughts; beyond which, the mind, whatever efforts it would make, is not able to advance one jot. ${ }^{35}$ $</$ ext $>$ 
The emphasis on 'boundaries' is supplied by James himself.

James describes Locke's principle as "eternally true"36 and he takes it to imply that, in the absence of the "sensational tang" of acquaintance, the congenitally blind person's so-called "knowledge" about the color blue must be declared "hollow and inadequate." 37 He maintains that, properly speaking, what the blind person "knows" about the color amounts merely to "the false conceit of knowledge." 38 On James's reading of Locke, then, complex ideas do not enable us to transcend the boundaries set by simple ideas. They keep us within those boundaries because they do not involve the kind of combination of ideas involved in definite descriptions. To go beyond those boundaries would require—from James's Locke's point of view, at least—our having_per impossibile — an idea of a particular that was not a simple idea of sensation or reflection, and so being able to talk about such a particular without thinking of it by means of simple idea. To be clear, I am not suggesting that this is an accurate interpretation of the historical Locke. I claim only that it captures how James was reading Locke.

In view of these remarks of James, it seems reasonable to suppose that he subscribed to- - or would, at least, have appeared to Russell to have subscribed to- the following thesis, which I shall refer to—merely for convenience—as "James's Principle":

$<$ ext>James's Principle: We cannot think about—or, consequently, have genuine knowledge about - particulars with which we are not, and have not previously been, acquainted. $</$ ext $>$

Not everything James says in his discussion of acquaintance is unarguably consistent with this principle. ${ }^{39}$ Nonetheless, his adherence to it is, I would argue, suggested by the remarks of his that I have quoted. 
At any rate, I would suggest that it is "James's Principle" that Russell means to be disputing in $O D$ when he emphasizes our ability to know by description particulars with which we are not acquainted. "All thinking," Russell says, "has to start from acquaintance; [nonetheless] it succeeds in thinking about many things with which we have no acquaintance" (OD, Papers, 4:415; emphasis in the original). ${ }^{40}$ This claim begins with a concession to James: acquaintance is indeed an enabling condition of thought (and knowledge). But it ends with a criticism of him: whereas, for James, acquaintance both furnishes the resources for thinking and circumscribes the domain of things we can think about, for Russell, it plays only the former role. ${ }^{41}$

In Russell the spirit of James's view is thus preserved at the expense of its letter. For Russell, as for James, all thinking has to start from acquaintance. The primitive constituents of propositions must, according to the $P O A$, be items with which we have acquaintance. But that does not mean it must end there; for we can use denoting concepts to think about things with which we are not acquainted, so long as we are acquainted both with those denoting concepts themselves and with their constituents. "Sensations," James had said, "are the stable rock, the terminus a quo and the terminus ad quem of thought." 42 Russell endorses the "a quo" — or at any rate a version of it amended to accommodate his view that we are acquainted with universals—but he rejects the "ad quem." And, accordingly, he insists that denoting enables us_-as he would later put it—to "pass beyond the limits of our private acquaintance" $(P O P, 59) .{ }^{43}$

These reflections on James, it should be noted, help to explain the equivocation, noted at the close of section 1 , in Russell's use of the word 'about' in $K A K D$. Insofar as he wishes to emphasize James's point about the need to anchor thought in acquaintance, he will want to say that all thought is 'about' things with which we have acquaintance. On the other hand, insofar as he wishes to emphasize the point that denoting shows James to be mistaken in his claim that acquaintance sets limits to thought and knowledge, he will want to say that we can think thoughts about things with 
which we lack acquaintance. The first point requires the stricter, and the second the looser, sense of 'about.'

This last point is relevant to a recent observation that Levine makes about Russell's use of the notion of aboutness in OD. Levine argues that the stricter use of 'about' is Russell's official notion in $O D \cdot{ }^{44}$ If that is correct-and I think Levine's arguments on this point are persuasive- - one could explain Russell's departure from the official notion of aboutness in the second paragraph of $O D$ as motivated by his desire to use his example of "the center of mass of the Solar System at a definite instant" to reveal the inadequacy of James's epistemology of understanding — an epistemology that implies that we cannot talk about this object, even in the looser sense of this expression. ${ }^{45}$

4. Distinction B: Acquaintance versus Knowledge of Truths (Knowledge About)

Although he would plausibly have been aware of distinction $B$ from his renewed engagement with James in 1903, Russell fails to produce a satisfactory formulation of the distinction before 1911. He does draw some contrast between acquaintance and knowledge about in $O D$, but it cannot claim to be distinction $B$, for it is a contrast between things known by acquaintance and things known by description (Papers, 4:415) — a contrast, therefore, which relates more closely to distinction $A$ than to distinction $B$. The following question therefore arises: What might have so piqued Russell's interest in distinction $B$ in 1911 that he should have come, in the summer of that year, to feel the need to formulate it more carefully than hitherto?

Part of the answer, I think, is that by this time Russell had come to take a special interest in certain epistemological distinctions as a result of having hit upon a general scheme for classifying knowledge. "Doing [POP]," he wrote to Lady Ottoline in the summer of 1911, "has given me a map 
of the theory of knowledge, which I hadn't [possessed] before." 46 The "map" in question is the taxonomy of knowledge introduced in the fifth chapter of POP and returned to in the tenth. According to this classification, knowledge in general divides into knowledge of things and knowledge of truths. ${ }^{47}$ Each species of knowledge further divides into a direct (or "immediate") and an indirect (or "derivative") form. Immediate knowledge of things is "acquaintance," while derivative knowledge of things is "knowledge by description." Immediate knowledge of truths, on the other hand, is "intuitive knowledge," while derivative knowledge of truths is knowledge of claims “deduced from self-evident truths by the use of self-evident principles of deduction" $(P O P, 109)$. Finally, immediate knowledge of things_acquaintance_-subdivides into acquaintance with particulars and acquaintance with universals $(P O P, 109) . \quad$ Russell's newfound clarity about the philosophical geography of knowledge partly explains his having arrived at a proper formulation of distinction $B$ in 1911, but it is not, I think, the complete explanation. A second relevant factor would have been Russell's philosophical reading matter at this time. Distinction B is clearly marked in G. E. Moore's Some Main Problems of Philosophy, a draft of which Russell saw immediately prior to composing POP. ${ }^{48}$ Moreover, around this time Russell seems to have returned once again to James_-where distinction $B$ is particularly clearly marked. One presumes that he wished to refresh his memory of the latter's discussion of acquaintance in preparation for writing $K A K D$.

Internal evidence a return to James at this time is provided by the appearance in 1911—for the first time in Russell's work — of certain Jamesian examples and turns of phrase. These include Russell's use of James's example of knowledge of the causes of the toothache; ${ }^{49}$ his drawing attention to the existence in foreign languages of verbs corresponding to two different senses of "know," 50 and his inclusion within the range of the acquaintance relation of distances in our private tactile spaces. ${ }^{51}$ External evidence for the same hypothesis is provided by the fact that, after James's death in August 1910, Russell was called upon to write an appreciation of his philosophy for the 
Nation (Papers 6:286-89) - a notice that includes quotations from the Principles of Psychology. ${ }^{52}$

Yet a third part of the answer to our question about what might have caused Russell to formulate distinction $B$ more precisely in 1911 is, I believe, that around this time Russell becomes interested in defending a thesis about knowledge that presupposes this distinction. This is the thesis that knowledge by acquaintance is independent of knowledge of truths. This thesis, which I will call the "Independence Thesis," is enunciated in such remarks as the following:

$<$ ext $>$ Knowledge of things, when it is of the kind we call knowledge by acquaintance, is essentially simpler than any knowledge of truths, and logically independent of knowledge of truths. $(P O P, 46)^{53}$ $</$ ext $>$

$<$ ext $>$ We may have knowledge of a thing by acquaintance even if we know very few propositions about it— theoretically we need not know any propositions about it. (POP, 144; emphasis added) $</$ ext $>$

Knowledge of truths, then, is one kind of epistemic state, and knowledge of things by acquaintance quite another — and "theoretically" one may have knowledge of a thing by acquaintance without knowing a single truth about it.

The development that explains Russell's interest in the Independence Thesis is-or so I want to claim — a new twist in his long-running dispute with Monistic Idealism. Such a development seems likely to have been prompted by his engagement at this time with the work of his transatlantic 
allies, the so-called "American Realists." This group of philosophers had just the previous year published a manifesto entitled "The Program and First Platform of Six Realists." 54 In this article, which Russell read soon after its publication, the six American Realists set out their anti-Idealist agenda in a series of short and rather dogmatic manifestos. Russell's article, "The Basis of Realism," of March 1911 (Papers, 6:130) was inspired by the Realists' article and constitutes, in effect, a seventh (less dogmatic) statement of the Realists' position.

Several of the things Russell says in POP echo particular theses that are propounded by the American Realists. And he seems to have wanted to reinforce his allies' positions by offering arguments for them wherever he could. This is where distinction $B$ and the Independence Thesis would have come into their own. For they provide grounds for one of the more important points made by the Realists, namely, an affirmation of the idea that knowledge grows in a piecemeal fashion. This point is made by Edward Gleason Spaulding in the final contribution to the Realists' article. "Any entity," says Spaulding, "may be known as it really is in some respects without its being known in all respects and without the other entities to which it is related being known, so that knowledge can increase by accretion." 55

Spaulding's view is directly opposed to the holistic view of knowledge that one Monistic Idealist, Harold Joachim, puts in the following terms:

$<$ ext $>$ Immature knowledge of some or all of the Parts is immature knowledge of the Whole, and full knowledge of the Whole is full knowledge of each and all of the Parts. Nor is the passage from immature to full knowledge the addition of perfect knowledge, bit to bit. (The Nature of Truth, 102; emphasis added)

$</$ ext $>$ 
Russell sides with Spaulding in wanting to defend the idea that knowledge can grow, so to speak, in dribs and drabs. And he is at pains to emphasize, against Joachim, that the particular bits of knowledge that get added to our stock of knowledge as it grows qualify as pieces of perfect knowledge in spite of falling short of knowledge of the whole.

It is here that distinction $B$ and the Independence Thesis that it makes possible become important. For Russell recognizes that in order to defend the piecemeal conception of knowledge acquisition he will need to block the argument standardly given for the Monistic Idealist's holistic conception of knowledge. Before turning to that argument, however, it will be convenient to first examine the famous passage from $P O P$ in which Russell advances a thesis that is intimately bound up with his piecemeal conception of knowledge-acquisition. I shall call it his "Perfect Knowledge Thesis":

$<$ ext $>$ Russell's Perfect Knowledge Thesis: We (nonomniscient beings) can-and sometimes do- - have perfect and complete knowledge of particulars and other proper parts of the universe.

$<$ ext $>$

The thesis is advanced toward the end of the following passage from POP:

$<$ ext $>$ We shall say that we have acquaintance with anything of which we are directly aware, without the intermediary of any process of inference or any knowledge of truths. Thus in the presence of my table I am acquainted with the sense-data that make up the appearance of my table_-its colour, shape, hardness, smoothness, etc... The particular shade of colour that I am seeing may have many things said about it — I may say that it is brown, that it is rather dark, and so on. But such statements, though they make me know truths about the colour, do not make 
me know the colour itself any better than I did before: so far as concerns knowledge of the colour itself, as opposed to knowledge of truths about it, I know the colour perfectly and completely when I see it, and no further knowledge of it itself is even theoretically possible. Thus the sense-data which make up the appearance of my table are things with which I have acquaintance, things immediately known to me just as they are. (POP, 46-47; emphasis added) $</$ ext $>$

As David Kaplan has observed, Russell's claim that, when he sees the color in question, he knows it "perfectly and completely" comes somewhat out of the blue. ${ }^{56}$ One wonders, first: What exactly is it to know something "perfectly and completely"? Second: What are Russell's grounds for claiming that the knowledge that we have of the color brown in virtue merely of seeing it has this special character? And, third: What, if anything, is the broader philosophical significance of this claim? These questions will concern us for the next two sections, but before we begin it will help to get clearer about the identity of the object that Russell takes us to know "perfectly and completely."

Russell tells us that this object is a "colour," but since he uses this term sometimes for a universal and sometimes for a particular it is not immediately clear what he has in mind. ${ }^{57} \mathrm{~A}$ little reflection, however, suggests that in this context what he must mean by "the colour brown" is not the universal, brownness, but rather a particular that instantiates this universal. For the passage indicates that the brown color in question is supposed to be a sense-datum-and sense-data, for Russell, are always particulars. ${ }^{58}$ (That sense-data are not universals is clear from the following remark: "All knowledge of truths ... demands acquaintance with things which are of an essentially different character from sense-data, the things ... which we shall call 'universals' " [POP, 48].)

5. The Meaning of 'Perfect and Complete' 
What does Russell mean to suggest by affirming that when he sees the brown color of his table he knows it "perfectly and completely"? Obviously, he does not mean that acquaintance gives us all the knowledge we will ever get about the brown sense-datum in question. For he knows that we could go on to learn, for example, that it is brown. This suggests that the word 'itself in Russell's articulation of his Perfect Knowledge claim must be intended somehow to forestall this incorrect reading. The same thought is suggested by his going on to say "and no further knowledge of it itself is even theoretically possible" (emphasis added).

What contrast is the word 'itself supposed to mark? We might be tempted to take Russell to be saying that acquaintance with a sense-datum gives us knowledge of all the intrinsic as opposed to relational truths about that sense-datum. But the temptation is better resisted, for Russell's espousal of the Independence Thesis makes such an interpretation unavailable.

I want to suggest that the word 'itself is merely intended to convey the idea that we have perfect knowledge by acquaintance with the sense-datum as opposed to perfect knowledge about it. But before developing this point, we would do well to consider a remark that occurs toward the end of the brown sense-datum passage_-one that might seem to cast doubt on Russell's purported allegiance to the Independence Thesis. Russell says that the sense-data that he sees in the presence of his table are "things immediately known to me just as they are" (POP, 47). This might seem to suggest that, when I am acquainted with a sense-datum, I know all the propositions that express truths about its intrinsic nature. But if that is what it means, Russell could hardly be consistent in his adherence to the Independence Thesis. How is this apparent tension to be resolved?

The answer, I believe, is that this last remark should be taken to register Russell's rejection of the Monistic Idealists' view—itself a consequence of their so-called "axiom of internal relations"that the known object is "modified" by standing to the knower in the relation of being known. According to such an interpretation, Russell is merely insisting-against this view-that, when I 
know a sense-datum by acquaintance, I know it "just as it is" in contrast with "as modified by the knowing mind.”

In support of this suggestion, we may note that if this consequence of the Monistic Idealists' so-called "axiom of internal relations" had not immediately occurred to Russell, he would have been reminded of it by two articles he had read shortly before composing POP. One is Ralph Barton Perry's essay of 1910, “The Egocentric Predicament,” which Russell discusses in his article, “The Basis of Realism"; the other is the aforementioned article, "The Program and First Platform of Six Realists. ${ }^{, 60}$ Moreover, there is some textual reason to expect that this consequence would have been salient for him at the time of composing POP, for in an article that appeared in the March of 1911 Russell says: "All arguments based on the contention that knowing makes a difference to what is known, or implies a community of interaction between knower and known, rest upon the internal view of relations and therefore fail when this view is rejected (Papers, 6:130).

Returning to our main theme, we need to ask: What, then, is the significance of the qualification 'itself,' if it is not to suggest that acquaintance gives us perfect knowledge of the intrinsic truths about the sense data? The answer, I would suggest, is that the word registers a qualification that is needed because the phrase 'having perfect knowledge of a thing' is apt to suggest the idea of possessing exhaustive knowledge of truths about that thing. If I am asked whether I know a certain philosopher in, say, France, I may say that although I do not know her personally, I do know of her. And that would normally be taken to mean that although I have not met her, I have heard enough about her to be incapable of truly claiming complete ignorance with respect to her. Given the naturalness of this kind of reading of the locution 'perfect knowledge by acquaintance of a sensedatum,' it behooves Russell to signal its inappropriateness in the present case by using the word 'itself.' The word, then, just serves to indicate that Russell is not propounding the obvious falsehood that he has perfect knowledge about the brown sense-datum when he sees it. 
So much, then, for the function of the word 'itself.' We now need to ask: What exactly would it be to have perfect knowledge by acquaintance of a particular sense-datum? Our answer must be constrained by the fact that Russell continues to advance the Perfect Knowledge Thesis even after explicitly declaring in 1914_quite possibly under the influence of James ${ }^{61}$ — that it would be a mistake to hold that acquaintance "had degrees" (Our Knowledge of the External World, hereafter cited as $O K E W, 151)$.

It is not clear whether such a view was already in place in 1911, though that is certainly possible. But, on the cautious assumption that Russell had not yet developed the all-or-nothing conception of acquaintance at that point, it is a relatively straightforward matter to come up with workable hypotheses about what "perfect and complete" knowledge by acquaintance of a sensedatum 'itself" might be. ${ }^{62}$ One possibility is that one has knowledge of this kind when and only when one is acquainted with every intrinsic fact about the object known by acquaintance (where an intrinsic fact about an object, $O$, is a fact into which $O$ enters as a constituent and in which the only other maximal constituent is an intrinsic property of $O) .{ }^{63}$ Such an understanding would be one way_compatible with Russell's other commitments_of cashing out Mark Johnston's idea that Russellian acquaintance puts the subject in a state of "revelation" with respect to the object of acquaintance ("How to Speak of the Colors," 223). Another possibility would be to suppose that a subject has perfect and complete knowledge by acquaintance when and only when she is acquainted with every part of the sense-datum in question. ${ }^{64}$

Once Russell adopts the view that acquaintance is an all-or-nothing affair, however, it is less clear that these interpretations are still available to him; for they seem to provide for the conceptual possibility of possessing less-than-perfect knowledge (by acquaintance) of the sense-datum. The situation is complicated, however, by Russell's official repudiation of primitive modality. Given that commitment, it is possible that all he means by denying that acquaintance "has degrees" is that one 
never will—as a matter of (what we would call) brute, contingent fact—find oneself in a state of partial or incomplete acquaintance with anything. If that is all that he means, then the interpretations just discussed would, after all, be available even as interpretations of Russell's 1914-18 view that in acquaintance we know sense-data "perfectly" or "fully." For, given his repudiation of primitive modality, his view could just be that as a matter of brute, contingent fact the sense-data with which we are, or ever will be, acquainted are ones with each of whose parts we are acquainted (or ones every intrinsic fact about which is an object of our acquaintance). However, since Russell seems not to be consistent in his rejection of primitive modality, ${ }^{65}$ we must, after all, be open to his making sense of the idea that it is a conceptual possibility on these readings that the object known by acquaintance might be known to a nonmaximal degree.

Accordingly, we need to ask: How would Russell have understood the notion of "perfect" or "full" acquaintance in 1914 or in 1918? And we must also ask: Is there any reason to think that at these stages he would have regarded imperfect knowledge by acquaintance as unintelligible—as, that is to say, not even a conceptual possibility? I believe that there may be.

One answer to the first of these questions has been suggested by Michael Tye, who interprets Russell as maintaining that one's knowledge by acquaintance with a sense-datum is perfect in the sense that it cannot be improved by one's learning truths about the sense-datum. ${ }^{66}$ The suggestion is tempting - what is perfect, after all, cannot be improved. But I think that it is nonetheless unsuccessful because one could contend with equal right that one's knowledge by acquaintance of a sense-datum is the most imperfect kind of knowledge that one has on the ground that it cannot be impoverished by one's forgetting truths about it. And since it would be-to borrow a Russellian turn of phrase- "sheer favoritism" to accord weight to one of these arguments and not the other, neither one can be adjudged uniquely correct. But since, equally, they cannot both be correct, we seem required to deem neither of them cogent. Tye's suggestion, then, will not do. 
A more promising idea, I think, is that Russell is using the phrase 'perfect and complete' allusively. He is conveying to the Monistic Idealists among his readers—without coming out and saying so directly — that knowledge by acquaintance is perfect by their lights. This suggestion draws strength from the fact that one of Russell's Idealist opponents, F. H. Bradley, in fact seems to think of perfection in a way that would suggest the view that imperfect knowledge of sense-data is not conceptually possible.

Bradley maintains — or seems to anyway — that to possess a gradable quality — a quality that could have various degrees - is in itself an imperfection, even if the quality in question should happen to assume its maximum value. He states this view_or what sounds like this view-in a chapter of Appearance and Reality that would likely have been of special interest to Russell, ${ }^{67}$ namely, the chapter on degrees of truth and reality. "The absolute, considered as such," says Bradley, "has of course no degrees; for it is perfect, and there can be no more or less in perfection." ${ }^{68}$ In order to explain Russell's treating our knowledge of sense-data as perfect and complete (on the assumption that it does not admit of degrees) we need only suppose that he read Bradley as maintaining that failing to admit of degrees was not merely necessary for perfection—as his remark clearly suggests—but also that it was sufficient.

Why does Russell not explicitly flag the anti-Idealist significance of his Perfect Knowledge Thesis? The reason, I think, is merely that, in the present context, to do so would be out of place. For at this point in the Problems Russell is concerned to argue that we are acquainted not with the table, but only with the sense-data it causes us to have. Russell's claim that I he knows the sense-data perfectly and completely is entered at this stage to convey - to those in the know-his opposition to the Idealist's commitment to epistemic holism—a moral that is only spelled out for the general reader much later in the book (in chapter 14). Russell can, I think, have felt some confidence that this allusion would not have been lost on his Idealist opponents, for the terms 'perfect' and 
'complete' (or, at least, 'entire') were epithets that—even if Bradley did not himself use them so straightforwardly—were widely believed to have been used as predicates characterizing the absolute. ${ }^{69}$ For Russell to apply them to a particular state of mind, then, would constitute the height of anti-Idealist provocation. $^{70}$

At any rate, the assumption that Russell is temporarily adopting the conception of 'perfection' suggested by Bradley and applying it to knowledge by acquaintance would, I think, fully explain his 1914 view that being "perfectly acquainted" with an object need not entail having exhaustive knowledge about it $(O K E W, 151)$. And it would also explain his view-stated in 1914 and 1918 — that our knowledge by acquaintance with a particular is "perfect" or "full," even though it does not come in degrees.

Since Russell's remark is allusive, he is not committed by this one use of the phrase "perfect and complete" to treating a quality that is "perfect" as never admitting of degree-and, indeed, he does speak elsewhere in POP of self-evidence as "perfect" in the sense that it is maximal along the relevant dimension $(P O P, 116) .{ }^{71}$ His point is rather to borrow this Bradlean language temporarily in order to draw attention to the fact—or to what he takes to be the fact—-that his Bradlean opponent is committed to counting our knowledge by acquaintance with a sense-datum as an instance of knowledge that is "perfect" in precisely the Bradley's sense.

On this reading, then, Russell's grounds for advancing the Perfect Knowledge Thesis are, first, that acquaintance is a species of genuine knowledge-an assumption that we will scrutinize in section 6-and second, that it does not, as a matter of conceptual necessity, have degrees. This, then, goes some way toward answering our second question. After 1914, Russell takes himself to be entitled to advance the Perfect Knowledge Thesis simply because he takes acquaintance to be a kind of knowledge that does not admit of degrees. If the all-or-nothing conception of acquaintance had not been in place prior to 1914, Russell's grounds for the Perfect Knowledge Thesis would have had 
to have been different. I sketch one possibile explanation of what these grounds might have beenon that assumption —in section 3 of "Russell on Substitutivity."

As Russell realizes, if he is to defend the Perfect Knowledge Thesis, he will need to disarm a certain argument that the Monistic Idealists offer against it. It is to this argument that we now turn.

6. Russell's Use of His Independence Thesis against Monistic Idealism

Russell presents the Monistic Idealist's argument against the Perfect Knowledge Thesis—or his take on it, at least — in a number of places, but most prominently in a series of lectures entitled "The Philosophy of Logical Atomism" (1918, hereafter cited as PLA). "[T] he logic that I should wish to combat," he says,

$<$ ext $>$ maintains that in order thoroughly to know any one thing, you must know all its relations and all its qualities, all the propositions in fact in which that thing is mentioned; and you deduce of course from that that the world is an interdependent whole. It is on a basis of that sort that the logic of monism develops. Generally one supports this theory by talking about the 'nature' of a thing, assuming that a thing has something which you call its 'nature' which is generally elaborately confounded [with] and distinguished from the thing, so that you can get a comfortable seesaw which enables you to deduce whichever results suit the moment. The 'nature' of the thing would come to mean all the true propositions in which the thing is mentioned. Of course it is clear that since everything has relations to everything else, you cannot know all the facts of which a thing is a constituent without having some 
knowledge of everything in the universe. (PLA, 204)

$</$ ext $>$

The argument Russell has in mind here in fact relies on various suppressed premises. Fully spelled out, it would run as follows. In order to know any particular thing thoroughly (alternatively, "perfectly," "fully," “completely"), one must know its "nature." But a thing's nature is the totality of truths about it. So, in order to know a thing thoroughly, one must know all its relations and qualities. But, by the Monistic Idealist's "axiom of internal relations," all relations are constituted by the natures of their terms. ${ }^{72}$ That is to say, there is nothing more to two things' standing in a given relation than their having the natures they do have. So, in order to know the relations into which anything enters, one must know the natures of all the things to which it is related, hence all the truths about those things. But since everything bears some relation to everything else, this would require one to know all the truths about the universe. Barring omniscience, then, none of us ever does know any particular thing thoroughly.

This argument does not, so far as I know, occur in precisely this form in the writings of any of Russell's Monistic Idealist opponents. In fact, it seems to be a mélange of two arguments of rather different provenance. ${ }^{73}$ The first is an argument that Russell attributes to Joachim in his 1906 article "On the Nature of Truth." It runs:

$<$ ext $>$ Assuming that we are not to distinguish between a thing and its "nature," it follows from the axiom [of internal relations] that nothing can be considered quite truly except in relation to the whole. For if we consider "A is related to B," the A and the B are also related to everything else, and to say what the $\mathrm{A}$ and the $\mathrm{B}$ are would involve referring to everything 
else in the universe $(1906,37)$.

$</$ ext $>$

The second argument is one presented by James in his article for Mind of 1882, "On Some Hegelisms," which was reprinted in The Will to Believe and Other Essays in Popular Philosophy of 1897. James, who does not endorse the argument himself, attributes it to Hegel and his followers. It runs:

$<$ ext $>$ Obviously until we have taken in all the relations, immediate or remote, into which the thing actually enters or potentially may enter, we do not know all about the thing. And obviously for such an exhaustive acquaintance with the thing, an acquaintance with every other thing, actual and potential, near and remote, is needed; so that it is quite fair to say that omniscience alone can completely know any one thing as it stands. [And since the thing inhabits] a world of relations, that world must be known before the thing is fully known. $(206)^{74}$

$</$ ext $>$

The first of these arguments resembles the one that Russell discusses in PLA insofar as it is presented as hinging on not distinguishing a thing from its "nature"; but it differs from the PLA argument in focusing not on the notion of knowing a particular quite fully, but merely on "considering it quite truly." The second argument resembles the argument under discussion in PLA insofar as it focuses on the conditions for having full knowledge of a thing, but it differs from it in making no reference to the "nature" of the known object, as well as in being directed against Hegel rather than the Monistic Idealists_-though, since Russell was in the habit of referring to the latter as "Hegelians," this last difference is minimal. ${ }^{75}$ 
Russell seeks to block the argument for epistemic holism at its first step: "When you have acquaintance with a particular," he says,

$<$ ext>you understand that particular itself quite fully, ${ }^{76}$ independently of the fact that there are a great many propositions about it that you do not know, but propositions concerning the particular are not necessary to be known in order that you may know what the particular itself is. ${ }^{77}$ (PLA, 204; emphasis added)

$</$ ext $>$

This remark is not entirely felicitous owing to the awkwardness of speaking of "understanding" the object of acquaintance. But that should not trouble us unduly; for Russell himself goes on to reproach the Monistic Idealists for speaking as though one could understand things other than symbols (PLA, 205). It therefore seems likely that here Russell is merely acquiescing in a misleading idiom for the sake of being intelligible to his opponents. He simply means that when one has acquaintance with a particular, one knows it (by acquaintance) quite fully.

The important point is that Russell is using the Independence Thesis to block an argument that would render the Perfect Knowledge Thesis untenable. His idea is to argue that, by the Independence Thesis, there is no reason to deny that I can (in a certain sense) know a particular quite fully even when I fail to know a single truth about it. The Idealist's argument is thus blocked at its first step. Russell, moreover, seems to have precisely this blocking strategy in mind in POP when he says: 
$<$ ext $>$ There is a confusion, when [the Hegelian's] use of the word 'nature' is employed, between knowledge of things and knowledge of truths. We may have knowledge of a thing by acquaintance even if we know very few propositions about it — theoretically we need not know any propositions about it. .... I may be acquainted, for example, with my toothache, and this knowledge may be as complete as knowledge by acquaintance ever can be, without knowing all that the dentist (who is not acquainted with it) can tell me about its cause, and without therefore knowing its 'nature' in the above sense. ... Thus, acquaintance with a thing does not involve knowledge of its 'nature' in the [Hegelian's] sense ... . It follows that we cannot prove that the universe as a whole forms a single harmonious system such as Hegel believes that it forms. (POP, 144-45) $</$ ext $>$

If our previous reflections have been on the right track, this passage is addressed both to Joachim and to (the followers of) James's Hegel.

That Russell's disagreement with Joachim should have surfaced in POP is not all that surprising. The two philosophers had locked horns frequenly during the Edwardian decade, and Russell was no doubt still spoiling for a fight. ${ }^{78}$ What may seem surprising, though, is that Russell should have left it until 1911 to wield the Independence Thesis against the argument for epistemic holism. ${ }^{79}$ In the light of our discussion, however, this should seem less surprising. For, as we have seen, Russell's interest in the anti-Idealist significance of distinction $B$ - and in the Independence Thesis that it makes possible_-did not arise until early 1911 when, stimulated by the work of the American Realists, he opened a new chapter in his dispute with Monistic Idealism.

Before we leave the topic of Russell's reaction to the Monistic Idealist's argument, we would 
do well to mention a second line of objection that he is plausibly (if less conspicuously) running in conjunction with his appeal to the Independence Thesis. This concerns Russell's opponents' equation of a thing with its "nature.” Russell clearly sees this move as pivotal in the Idealist's argument, and, equally clearly, he wishes to reject his opponents' conception of a thing's nature as the totality of truths about it. But it is worth noting that Russell's remarks also contain hints of a more subtle line of criticism—one that would run as follows. The Monistic Idealist assumes that knowing a thing thoroughly requires knowing its "nature." But knowing a thing's nature is just a matter of knowing what it is, which is, in turn, just a matter of knowing it by acquaintance. Consequently, for all the Idealist has shown, we might know a thing thoroughly without knowing any truths about it; for to do so we need only know it by acquaintance. The key move is the deflationary one of insisting that knowing a thing's nature is not a matter of knowing all the truths about it but merely a matter of knowing it by acquaintance.

This deflationary move is one that may well have been suggested to Russell by his rereading of James for, as we have already noted, James equates the knowledge given by acquaintance with knowledge of whats, and-more suggestively still—he himself plants the seeds of the deflationary move by affirming that sensation yields knowledge of "bare immediate natures" (Principles of Psychology, 2:3; emphasis added). (This remark seems to have resonated with Russell for he quotes it approvingly in TK [55]). ${ }^{80}$ Given this background, it should not be all that surprising that, when Russell insists in PLA that, owing to the Independence Thesis, we may know a thing itself "quite fully" even without knowing all the truths about it, he puts the point by saying that we may know "what the particular itself is" (emphasis added). He thus moves seamlessly between "knowing a thing (perfectly) by acquaintance" and "knowing what it is," and this slide is, he supposes, licensed by his view that there is no more to the latter than the former.

Returning to the main thread, we may note that these considerations suffice to answer our 
third main question about the Perfect Knowledge Thesis. Russell's motive for advancing this thesis is that its articulation constitutes a gauntlet-dropping provocation to the Monistic Idealists. He advances the Independence Thesis as a way of protecting the Perfect Knowledge thesis from the argument that his opponents would run against it. The broader philosophical significance of the Perfect Knowledge Thesis, then, is that it represents Russell's repudiation of the holistic epistemology of Monistic Idealism.

The reason why Russell makes this move in POP and not before is, I think, because at this point, having recently had distinction $B$ raised to salience for him, and having refreshed his knowledge of James, he feels in a position to defend the Perfect Knowledge Thesis against the Monistic Idealists' argument without resorting to his standard criticisms of the axiom of internal relations_-a line of criticism by which, as Russell was well aware, his opponents had hitherto been unmoved. It is even possibile that what seems to have been Russell's return to James shortly before composing POP would have suggested the Perfect Knowledge Thesis to him. For James in his 1885 article, "On the Function of Cognition," which was reprinted as a chapter of his 1909 book The Meaning of Truth, speaks of acquaintance as something that "it is hard to imagine susceptible either of improvement or increase, being in its way complete" $(1885,33)$. It seems likely that Russell would have been familiar at least with the reprinted version of this article; for he cites The Meaning of Truth in his Philosophical Essays of 1910, and, in the same work, he shows himself to be aware that one of its contained essays is a reply to one of his own articles (112).

This last remark from James brings out a point that is, I think, of independent interest. James, it seems, is already using 'acquaintance' as a technical term in the mid-1880s. After all, if it is indeed hard to imagine Jamesian acquaintance as "susceptible of improvement," then that kind of acquaintance is not what we ordinarily have in mind when we speak of someone as being acquainted with a place, a person, a state of affairs, or a body of work. Charles Dickens, for example, speaks- 
without detectable archness — of one of his characters as having first made the acquaintance of another at a certain establishment and as having subsequently "improved" that acquaintance. ${ }^{81}$ And the Oxford English Dictionary gives examples of one person's being better acquainted than another with some state of affairs. ${ }^{82}$ Nor is it at all strained to speak of one's acquaintance with an academic field or body of work as "limited" and so, presumably, capable of improvement. I conclude that it is not Russell who first goes against the grain of the language by using the word 'acquaintance' as a technical term for a state of knowledge that cannot in principle be improved.

7. Russell's Defense of Piecemeal Inquiry Appraised

How successful is Russell's defense of piecemeal inquiry? This is unclear, and for two reasons. First, the Monistic Idealist could argue that, even if Russell's argument were to prove successful, it would be irrelevant. For what Russell really needs to show is not that knowledge of things can grow in a piecemeal fashion, but that knowledge of truths can do so. Second, Russell's opponent could question his crucial assumption that acquaintance is a form of knowledge.

The first objection has prima facie force, but in order to evaluate it we would need to know more about how the Monistic Idealist intends to argue that all knowledge of truths is only imperfect or partial. If that argument is supposed to rest on the assumption that perfect knowledge of a truth about a thing requires knowledge of that thing's "nature," then Russell's blocking move will still apply; for he will be able to grant this assumption while denying that knowing something's nature amounts to anything more than knowing it by acquaintance. Unfortunately, however, the texts shed little light on how Russell takes his opponent to be arguing for this thesis about knowledge of truths, and the writings of the Monistic Idealists themselves are far from clear on this point. ${ }^{83}$ It is, 
therefore, hard to gauge the acuteness of the difficulty posed by this first objection.

The second objection, by contrast, is clearly pressing. It arises because, in order for Russell to construct a compelling counterexample to the Monistic Idealist's thesis that the Perfect Knowledge Thesis is false, it must be obvious beyond reasonable doubt that acquaintance is indeed genuine knowledge. But, unfortunately for Russell, that is not obvious. Indeed, doubts on this score had already arisen in Russell's time, and they are still with us today. ${ }^{84}$

Russell believes that acquaintance is genuine knowledge because he, following James and Grote, regards it as a species of what_-just to have a convenient term-I will call "thingknowledge." This is the kind of knowledge that is expressed in German by the verb "kennen" and in French by "connaitre." These verbs take noun phrases as complements and are contrasted with the verbs "wissen" and "savoir," which often take a that-clause as a complement. By the lights of contemporary semantics, the existence of these pairs of knowledge verbs in foreign languages does in fact constitute some evidence for the ambiguity of the English word "knows." Unfortunately, however, it is one thing to establish the probable existence of a distinct species of knowledge expressed by_for example_-"kennen" and "connaitre" (used with noun phrases as complements) and quite another to show that Russellian acquaintance qualifies as knowledge of this kind.

The worry is sharpened by Tim Crane's recent observation that there are a number of features that ordinary thing-knowledge seems to have that Russellian acquaintance arguably lacks. ${ }^{85}$ The first is that ordinary thing-knowledge seems to entail some truths. When one can be said to know New York, one always seems to know some truths about it. And if one knows absolutely nothing about New York, that fact would seem to undermine one's claim to know the city. The same does not hold, given the Independence Thesis, for Russellian acquaintance. Second, as we have already noted, ordinary thing-knowledge, unlike Russellian acquaintance (at least on Russell's 1914 conception of it), comes in degrees. Finally, ordinary thing-knowledge is always a standing state, 
while acquaintance need not be-and the paradigm case of acquaintance, namely, acquaintance with a sense-datum in perception, is not. Indeed, as Michael Tye points out, we should not expect acquaintance with a highly specific shade of color- $\mathrm{red}_{21}$, say- to consist in a standing state because our memories are incapable of storing the information that would be required to enable us to be nonepisodically acquainted with all the specific shades of color that come within our ken. ${ }^{86}$

Faced with these disanalogies, Russell might perhaps claim that this only goes to show that acquaintance is a species of thing-knowledge-one that differs from other species of this same genus in certain respects. The problem, however, is that at this point in the dialectic the burden of proof rests on him. In order to have a persuasive counterexample to the Monistic Idealist's argument against the Perfect Knowledge Thesis, Russell needs to make a compelling case for his view that acquaintance is genuine thing-knowledge. But the differences noted by Crane set this claim under a cloud.

\section{Conclusion}

I have been concerned to explore two aspects of Russell's interest in acquaintance and in the distinctions in which it figures, namely, his opposition to James's epistemology of understanding and to Monistic Idealism, respectively. I have emphasized these aspects, first, because I believe that they have been somewhat overlooked, and, second, because they help to isolate the distinctive roles played in Russell's philosophy by distinctions $A$ and $B$.

More fully, I have argued that, when Russell first formulates the $P O A$ in 1903 , his chief concern is to argue for the inadequacy of James's epistemology of understanding — a view on which acquaintance is treated not merely as an enabling condition of thought but also as a limiting condition of it. Both in $P A D$ and in $O D$ Russell argues implicitly that the phenomenon of 
knowledge by description shows that James is wrong to regard acquaintance as a limiting condition: it is merely an enabling condition. Accordingly, Russell—in effect, if not in intention—offers his $P O A$ as a replacement for what I have called "James's Principle." For the $P O A$ is—-more or lesswhat James's Principle becomes when it is modified to take account of our ability to know by description things with which we are not acquainted.

I have argued, further, that in 1911 Russell appeals to the Independence Thesis and to distinction $B$ in order to buttress his case against Monistic Idealism. His idea is to use this thesis to protect his claim that acquaintance with particulars yields perfect knowledge of those particulars "themselves" from the argument by which the Idealists would seek to undermine it.

Finally, I have made a case that Russell's notion of acquaintance changes in important ways under the influence of his engagement with James, and that it is this change that enables him to first formulate the $P O A$ using the notion of acquaintance in 1903.

Perhaps the most surprising thing that emerges from our investigation is a picture of the early Russell as more closely engaged with James's epistemology than has previously been supposed. The engagement is twofold. On the one hand, there is Russell's almost hidden dispute with James in $O D$ about the epistemology of understanding, and on the other, there is his systematic borrowing of certain aspects of James's epistemology, first, in shaping his conception of acquaintance, and, second, in the service of his dispute with Monistic Idealism. Russell agrees with James: first, that acquaintance is genuine knowledge; second, that knowledge by acquaintance affords complete knowledge of the known object "itself"; third, that acquaintance is an all-or-nothing affair; and, lastly, that knowledge by acquaintance is wholly independent of knowledge-about. It is even possible that Russell's strategy of deflating the notion of knowing a thing's "nature" to knowing it by acquaintance is inspired by a hint of this idea in James. At any rate, Russell's engagement with James's epistemology seems to be as profound as it is pervasive. And-I would argue-it plausibly 
lends new momentum — if not, at the end of the day, new force — to his case against Monistic Idealism. $^{87}$

\section{Abbreviations}

KAKD: Knowledge by Acquaintance and Knowledge by Description" ([1911] in Papers, 6).

ML: $\quad$ Mysticism and Logic (Russell 1981 [1917]).

OD: “On Denoting” (Russell 1956 [1905]; in Marsh, ed., 1956).

OF: $\quad$ "On Fundamentals," in Papers, 4:359-413.

OKEW: $\quad$ Our Knowledge of the External World (Russell 1993 [1914]).

OMA: Ottoline Morrell Archive. Harry Ransom Center, University of Texas at Austin.

OMD “On Meaning and Denotation," in Papers, 4:314-58.

PAD "Points about Denoting," in Papers, 4:305-13.

Papers The Collected Papers of Bertrand Russell.

PLA The Philosophy of Logical Atomism (in R. Marsh, ed., Logic and Knowledge: Essays, 19011950, 1956 [1918]).

PM Principia Mathematica (Russell and Whitehead 1990 [1910]).

POA Principle of Acquaintance.

POP The Problems of Philosophy (Russell 1959 [1911]).

Principles The Principles of Mathematics (Russell 1996 [1903]).

TOK Theory of Knowledge (Russell 1992 [1913]). 


\section{Bibliography}

Bradley, Francis. Herbert. Appearance and Reality: A Metaphysical Essay. Oxford: Clarendon, 1930. Originally published 1893. [Appearance and Reality]

—. The Principles of Logic. London: Oxford University Press, 1922. Originally published 1883. Candlish, Stewart. The Russell/Bradley Dispute and Its Significance for Twentieth- Century Philosophy. Basingstoke: Palgrave Macmillan, 2007. [Russell/Bradley Dispute]

Crane, Tim. "Tye on Acquaintance and the Problem of Consciousness." Philosophy and Phenomenological Research 84, (2012): 190-98. doi:10.1111/j.1933-1592.2011.00557.x. [“'Tye on Acquaintance"]

Dickens, Charles. A Tale of Two Cities, London: Penguin. 2003. Originally published 1859.

Fawcett, E. D. “'The Ground of Appearances” Mind 20 (1911): 197-211.

Frege, Gottlob. 1980. Philosophical and Mathematical Correspondence. Edited by G. Gabriel et al. Chicago: University of Chicago Press, 1980. Abridged from the German edition by Brian McGuinness and Hans Kaal.

Geach, Peter. Mental Acts. London: Routledge and Kegan Paul, 1957.

Griffin, Nicholas, ed. The Selected Letters of Bertrand Russell. Vol. 1. Boston: Houghton Mifflin, 1992. [Selected Letters]

Grote, John. Exploratio Philosophica: Rough notes on modern intellectual science. Part 1. Cambridge:

Deighton, Bell, 1865. [Exploratio Philosophica]

Helmholtz, H. von. Popular Scientific Lectures. New York: Dover, 1962. Originally published 1881.

Holt, E. B., et. al. "The Program and First Platform of Six Realists." Journal of Philosophy, Psychology and Scientific Methods 7(1910): 393-401. ["Program and First Platform"]

Hylton, Peter. Russell, Idealism and the Emergence of Analytic Philosophy. Oxford: Oxford University Press, 1990.

James, William. “The Knowing of Things Together.” Psychological Review. 2 (1895), 105-24. 
—. The Meaning of Truth. Cambridge, MA: Harvard University Press, 1979. Originally published 1909.

- Memories and Studies. New York: Longmans, Green, 1911.

—. "On the Function of Cognition." Mind 10 (1885), 27-44.

—_."On Some Hegelisms.” Mind 7 (1882), 186-208.

—. The Principles of Psychology. 2 vols. New York: Dover, 1950. Originally published 1890.

—. Some Problems of Philosophy: A Beginning of an Introduction to Philosophy. New York:

—. Psychology. New York: Henry Holt, 1892

—. The Will to Believe and other Essays in Popular Philosophy. New York: Longmans, Green, 1897. [Will to Believe]

Longmans, Green, 1911. [Some Problems of Philosophy]

Joachim, Harold. “' 'Absolute' and 'Relative’ Truth.” Mind 14 (1905): 1-14.

—. The Nature of Truth. Oxford: Clarendon, 1906.

Johnston, Mark. "How to Speak of the Colors.” Philosophical Studies 68 (1992): 221-63.

Kaplan, David. “ ‘On Denoting’ on Its Centenary.” Mind 114 (2005): 933-1003.

Locke, John. An Essay Concerning Human Understanding. Edited by P. H. Nidditch. Oxford. Clarendon, 1990.

Levine, James. "Aboutness and the Argument of 'On Denoting," in On Denoting 1905-2005. Edited by Bernard Linsky and Guido Imaguire. Munich: Philosophia Verlag, 2005, 1-69.

—_. “Acquaintance, Denoting Concepts, and Sense.” Philosophical Review 107 (1998): 41445. 
Ludlow, P. "Descriptions.” In The Stanford Encyclopedia of Philosophy. Stanford University, Winter 2011 edition. Edited by Edward N. Zalta. http://plato.stanford.edu/archives/win2011/entries/descriptions/.

Marsh, R., ed. Logic and Knowledge: Essays, 1901-1950. London: Unwin Hyman, 1956.

Miah, Sajahan. Russell's Theory of Perception, 1905-1919. London: Continuum, 2006.

Milkov, Nikolay. 'The History of Russell's Concepts 'Sense-Data' and 'Knowledge by Acquaintance.' " Archiv für Begriffsgeschichte 43 (2001): 221-31.

Moore, G. E. “The Refutation of Idealism,” Mind 12 (1903).

—. Some Main Problems of Philosophy. London: Allen and Unwin, 1953.

Passmore, John. A Hundred Years of Philosophy. New York: Basic Books, 1966. [Originally published 1957].

Pears, David. “The Function of Acquaintance in Russell's Philosophy.” Synthese 46 (1981): 149_ 66. [Function of Acquaintance]

Perry, Ralph Barton. "The Egocentric Predicament.” Journal of Philosophy, Psychology and Scientific Methods 7 (1910): 5-14.

Proops, Ian. “Acquaintance, Certainty, and Error in Russell's Problems of Philosophy." Forthcoming in Bernard Linsky and Donovan Wishon, eds, Acquaintance, Knowledge and Logic: New Essays on Bertrand Russell's The Problems of Philosophy.

—. "Russell on Substitutivity and the Abandonment of Propositions." Philosophical Review 120 (2011): 151-205. [“Russell on Substitutivity”]

Russell, Bertrand. The Collected Papers of Bertrand Russell. Vol. 1: Cambridge Essays, 1888-99. Edited by Kenneth Blackwell. London: Allen and Unwin, 1988. [Papers, 1]

- The Collected Papers of Bertrand Russell. Vol. 4, Foundations of Logic, 1903-05. $\quad$ Edited by A. Urquhart with the assistance of A. C. Lewis. London: Routledge, $1994 . \quad$ [Papers, 4] 
- The Collected Papers of Bertrand Russell. Vol. 6, Logical and Philosophical Papers, 1909-13.

Edited by J. G. Slater with the assistance of B. Frohmann. London: Routledge, 1992. [Papers, 6]

. The Collected Papers of Bertrand Russell. Vol.7, Theory of Knowledge: The 1913 Manuscript.

Edited by E. R. Eames. London: Allen and Unwin 1984.

- The Collected Papers of Bertrand Russell. Vol. 8, The Philosophy of Logical Atomism and Other

Essays, 1914-19. Edited by J. G. Slater. London: Allen and Unwin, 1986. [Papers, 8]

—. Essays in Analysis. Edited by D. Lackey. New York: George Braziller, 1973.

-. Mysticism and Logic. Totowa, NJ: Barnes and Noble, 1981. Originally published 1917. $[M L]$

—. "On Denoting." Reprinted in R. Marsh, ed., Logic and Knowledge: Essays, 1901-1950, 41-56. Originally published in Mind, n.s., 14 (1905): 479-93. [OD]

-. "On the Nature of Truth." Proceedings of the Aristotelian Society 7 (1906): 28-49. Paper delivered to the Aristotelian Society, December 3, 1906.

- Our Knowledge of the External World. London: Routledge, 1993. Originally published 1914. $[O K E W]$

—. The Principles of Mathematics. New York: Norton, 1996. Originally published 1903. [Principles $]$

. Problems of Philosophy. Oxford: Oxford University Press, 1959. Originally published 1912
$[P O P]$ - Theory of Knowledge: The 1913 Manuscript. Edited by E. R. Eames. London. Routledge, 1992. [TOK]

Russell, Bertrand, and Alfred North Whitehead. Principia Mathematica to *56. Cambridge: Cambridge University Press, 1990. Originally published 1910; 2nd ed. 1927. [PM]

Sellars, Wilfrid. Empiricism and the Philosophy of Mind. Cambridge, MA: Harvard University Press, 1997. Originally published 1956. [Empiricism] 
Stanley, Jason. Know How. Oxford: Oxford University Press, 2011.

Tye, Michael. Consciousness Revisited. Cambridge, MA.: MIT Press, 2009.

—. "Reply to Crane." Philosophy and Phenomenological Research 84 (2012): 215-17. doi:10.1111/j.1933-1592.2011.00560.x.

Whately, Elizabeth J. Life and correspondence of Richard Whately, D.D., late Archbishop of Dublin, London: Longmans, Green and Company.1866.

\footnotetext{
${ }^{1}$ See, for example, Geach, Mental Acts, 46, and Ludlow, “Descriptions” 2011, §3.3.

${ }^{2}$ The view is most memorably expressed in his remark to the effect that "the particular facts of sense" are, like the truths of logic, "hard data" that resist "the solvent influence of critical reflection" (Russell, OKEW 1914, 70-71).

${ }^{3}$ To say this is not to deny that $P O P$ also contains certain remarks that can appear to suggest that Russell believes that when we have acquaintance with a sense-datum we can be certain that it exists. I attempt to show that these appearances are misleading in my article "Acquaintance, Certainty, and Error in Russell's Problems of Philosophy." Forthcoming in Bernard Linsky and Donovan Wishon, eds, Acquaintance, Knowledge and Logic: New Essays on Bertrand Russell's The Problems of Philosophy.

${ }^{4}$ Although Russell on one occasion characterizes knowledge of truths as involving knowledge that something is the case $(P O P, 44)$, it would be wrong to think that ascriptions of such knowledge are confined to idioms of the form "S knows that $p$ " (and its literal translations into other languages). For "knowledge of a truth" on his conception would also be reported by sentences lacking any thatclause, for example, the sentence: "John knows himself to be a poor driver." This kind of
} 
construction is, moreover, the standard way of reporting knowledge of truths in certain languagesClassical Latin, for example.

${ }^{5}$ John Passmore, for example, claims that Russell took from James and Grote distinction $A$, whereas what he actually took from these authors is distinction B. See Hundred Years of Philosophy, 232. For similar conflations, see Tye, Consciousness Revisited, 97, and Miah, Russell's Theory of Perception, 13. As we shall see, Russell must himself bear some of the blame for these conflations since in $O D$ he uses the language of distinction $B$ in distinguishing objects known by acquaintance from objects known by description (Papers, 4:415).

${ }^{6}$ Papers, 4:306-13.

${ }^{7}$ The principle is variously formulated, and its significance shifts with changes in Russell's conception of the bearer of truth and falsehood, but the following formulation is representative: "Every proposition which we can understand must be composed wholly of constituents with which we are acquainted" (POP, 58; KAKD, 154).

${ }^{8}$ This last point is argued for in section 4 below. With regard to the point about indebtedness to James we may note that in The Principles of Psychology James introduces distinction $B$ in the following terms:

There are two kinds of knowledge broadly and practically distinguishable: we may call them respectively knowledge of acquaintance and knowledge-about. Most languages express the distinction; thus $\gamma v \omega v \alpha \imath, \varepsilon \imath \delta \varepsilon v \alpha l$; noscere, scire; kennen, wissen; connaître, savoir. (Principles of Psychology, 2:221)

In presenting such a list of verb pairs James is in fact merely following Grote (Exploratio Philosophica, 60), who had already distinguished between "knowledge of acquaintance with things" and "knowledge of facts about things" (123). James quotes the relevant passage from Grote at length in 
his 1885 article for Mind, "On the Function of Cognition" (31). See also Helmholtz, Popular Scientific Lectures, 179. James, however, departs from Grote and Helmholtz in one important respect. He does not allow that acquaintance can be an indirect relation—one mediated by pictures or representations_-as Grote (60) and Helmholtz (179) had supposed. For James, knowledge by means of a representation and knowledge by means of acquaintance belong on opposite sides of the divide between conceptual and intuitive knowledge_-see his 1895 article, “The Knowing of Things Together," 73-75. (I am grateful to Michael Kremer for drawing my attention to James's article of 1885.)

${ }^{9}$ Russell took James not to have distinguished between acquaintance and sensation. See Papers 7: 55.

${ }^{10}$ Here, I amend Russell's actual example, "Smith's wife," in the obvious way.

${ }^{11}$ Of course, the amended example remains problematic owing to polygamy.

${ }^{12}$ Compare, Papers, 6:148. But note that, since he acknowledges that acquaintance is sometimes a standing state, Russell goes on to qualify his equation of acquaintance with the converse of the relation of presentation.

${ }^{13}$ In a note added to POP in 1943 Russell claims that he composed this work in the early part of 1912. But his letters to Lady Ottoline show this recollection to be inaccurate. In truth, Russell composed the book between June 23, 1911, when he made a "new start with the shilling shocker," and August 20, when he reported having just finished his "book for the Middle West" (see Rusell to to Ottoline Morrell, June 23, 1911, Ottoline Morrell Archive, Harry Ransom Center (hereafter $O M A)$, The University of Texas at Austin, and also Russell to Lucy Donnelly, August 20, 1911, The Selected Letters of Bertrand Russell, ed. Griffin 1:387).

${ }^{14}$ Here, I ignore certain subtleties of use and mention. I am grateful to Russell Wahl and to James Levine for help in arriving at this formulation. 
${ }^{15}$ I shall use "genuine Russellian name" for unanalyzable names of both particulars and universals in preference to the more traditional label "logically proper name." I do so because Russell seems not to have used this latter label (see Proops, "Russell on Substitutivity" 152n2: 177 and note 28 below). ${ }^{16}$ He says: "We know that the candidate who gets the most votes will win ... but we do not know which of the candidates he is, i.e. we do not know any proposition of the form 'A is the candidate who will get the most votes' where A is one of the candidates by name” (Papers, 6:151). The context suggests that Russell is temporarily treating " $\mathrm{A}$ " as a genuine Russellian name. The problems for Russell's treatment of "knowing which" are not few, but I will not discuss them here.

${ }^{17}$ See what follows the second "although" in the remark just quoted.

${ }^{18}$ For a second instance of this implicit equation, see note 77 and the passage to which it relates.

${ }^{19}$ If linguists are to be believed, knowledge-what, being a species of knowledge- $w h$, is propositional and so cannot amount to the nonpropositional knowledge that Russell takes it to be. See chap. 2 of Stanley, Know How, for a discussion of relevant literature.

${ }^{20}$ The influence of James was_-so far as I know_first noted by John Passmore, Hundred Years of Philosophy (1957), 232. The thesis of influence is seconded by Nikolay Milkov, "History of Russell's Concepts 'Sense-Data' and 'Knowledge by Acquaintance,'” 230. Russell read James's Principles of Psychology in the mid-1890s (Papers, 1:354-55), and he discusses it in various articles published between 1896 and 1897. I offer evidence of Russell's later engagement with James on acquaintance throughout the paper.

${ }^{21}$ James, Psychology (1892).

${ }^{22}$ James, Principles of Psychology, 2:3.

${ }^{23}$ As we will see in section 4 below, there is reason to think Russell reread James in preparation for writing $K A K D$.

${ }^{24}$ Levine, “Acquaintance, Denoting Concepts, and Sense," 420. 
${ }^{25}$ Here it is relevant that Grote and Helmholtz had countenanced a notion of indirect acquaintance_-acquaintance mediated by pictures or representations. See note 8 above for details. ${ }^{26}$ Given his official—yet arguably, in practice, not consistently applied—repudiation of full blooded or primitive modality, how much emphasis Russell would or could put on the modal notion of truthconditions is unclear.

${ }^{27}$ The term "aboutness shifter" comes from Gideon Makin The Metaphysicians of Meaning (18)

${ }^{28}$ In fact, the term 'logically proper name' seems to be the creation of Russell's commentators, who never, so far as I know, accompany attributions of this term of art to Russell with a textual citation. ${ }^{29}$ I say "quasi-semantic" because the bearers of the designation relation are psychological rather than linguistic. In $O M D$ Russell speaks of "transferring the nomenclature adopted for phrases" to ideas, and so speaking of the latter as expressing meanings and as designating objects. (Papers 4:322)

${ }^{30}$ Griffin, Selected Letters, 250, 254.

31 “The Refutation of Idealism," 453.

${ }^{32}$ Later Russell uses the point against certain arguments he thinks he finds in Ralph Barton Perry that purport to show that we cannot know of the existence of anything with which we are not acquainted (POP 43; Papers, 6:130).

${ }^{33}$ James, Principles of Psychology, 2:6.

${ }^{34}$ James, Principles of Psychology, 2:3; emphasis added.

${ }^{35}$ Locke, Essay Concerning Human Understanding, bk. 2, chap. 23, p. 29; quoted in James, Principles of Psychology, 2:6.

${ }^{36}$ James, Principles of Psychology, 2:3.

${ }^{37}$ James, Principles of Psychology, 2:7.

${ }^{38}$ James, Principles of Psychology, 2:7. 
${ }^{39}$ One might take his remark that "of the mental states of persons we only have conceptual knowledge" as suggesting that we do indeed have knowledge of something we cannot be acquainted with. But it is equally possible that James would take "knowledge" of this purely conceptual kind to be, like the congenitally blind person's "knowledge" of the color blue, merely the "false conceit of knowledge."

${ }^{40}$ Again, in Russell's more relaxed sense of “about."

${ }^{41}$ Russell, it is true, does not identify James explicitly as his target here, but it is not without precedent for him to leave his (true) targets unnamed. For one thing — as is by now well knownRussell's true target in his famous Gray's Elegy argument in “On Denoting” is his own former view_ or views — about the meanings of denoting phrases and not Frege's historical views. For another, he leaves his opponents unmentioned in the chapter on Idealism in POP when he remarks: "It is often said, as though it were a self-evident truism, that we cannot know that anything exists which we do not know. It is inferred that whatever can in any way be relevant to our experience must be at least capable of being known by us" (POP, 43). It takes a bit of detective work to figure out that Russell's unnamed targets here are Ralph Barton Perry's opponents in his article of 1910, “The Egocentric Predicament” (compare Papers 6: 130). Nor, it should be mentioned, does Russell name his targets when criticizing the existential theory of judgment — the view that all judgments are about what exists (Principles, 427). Finally, as I shall argue in sections 5 and 6 below, there is excellent reason to suppose that Russell is engaging in an unannounced disagreement with unnamed opponents when he claims that, when we see the brown color of his table, we know it "perfectly and completely" (POP 46-47). ${ }^{42}$ James, Principles of Psychology, 2:7.

${ }^{43}$ Russell, I take it, means that denoting enables us to pass beyond the limits of our private knowledge of particulars — limits that would be imposed if we had knowledge only of truths about 
things with which we are acquainted. In considering this remark it is important to bear in mind that Russell continues to speak of definite descriptions as having a denotation even after he has abandoned denoting concepts. In $K A K D$, for example, the denotation of the denoting phrase "the $F$ " is said to be $x$ just in case "the $F=\chi$ " is true (Papers, 6:160) (Here, I disregard niceties of use and mention). The same point is made less explicitly in OD (Papers, 4:423).

${ }^{44}$ Levine, "Aboutness," 9-11.

${ }^{45}$ I owe this point to Levine in conversation.

${ }^{46}$ Russell to Ottoline Morrell, July 13, 1911 OMA.

${ }^{47}$ A minor terminological complication arises because Russell in fact uses the phrase "knowledge of things" ambiguously. On some occasions, he uses it to cover both knowledge by acquaintance and knowledge by description $(P O P, 46)$, but, on others, he reserves it for knowledge of a thing by acquaintance $(P O P, 44,135)$. Only the former usage accords with his official taxonomy.

${ }^{48}$ Moore, Some Main Problems of Philosophy, 81. Moore calls knowledge that "knowledge proper" and distinguishes it from direct and indirect apprehension, which correspond to direct and indirect acquaintance. Interestingly, he differs from Russell in treating apprehension always as an episodic state, as well as by treating standing knowledge of things as constituting yet a fourth variety of knowledge.

${ }^{49}$ James, Principles of Psychology, 2:7; compare POP, 144-45.

${ }^{50}$ POP, 44; Principles of Psychology, 1:221.

${ }^{51}$ James says "I know an inch when I move my finger through it" (Principles of Psychology, 1:221). Compare POP, 32.

${ }^{52}$ I owe this point to Nicholas Griffin.

${ }^{53}$ Compare: "Acquaintance ... does not, theoretically at least, imply even the smallest 'knowledge about" " (Russell, OKEW, 151). 
${ }^{54}$ Holt, "Program and First Platform."

${ }^{55}$ Holt, "Program and First Platform," 401.

${ }^{56}$ Kaplan, “ ‘On Denoting’ on Its Centenary,” 994.

${ }^{57}$ For example, in $P O P$ he at one point speaks of a red round sense-datum as having "both colour and shape" (POP, 114).

${ }^{58}$ In maintaining that the brown color discussed in this passage is supposed to be a particular sensedatum, I depart both from Johnston (“How to Speak of the Colors," 223) and from Tye (Consciousness Revisited, 97).

${ }^{59}$ This section has benefited from discussions with Rachel Abrams and Peter Hylton.

${ }^{60}$ Perry's "egocentric predicament" is the view that one cannot gauge how far, if at all, the mind "modifies" the objects it knows in the act of knowing them because one cannot encounter those objects outside of every relation to the knowing mind (see Perry, "Egocentric Predicament"). Perry's main question is whether the fact that I stand in such an egocentric predicament entails that the objects I know depend for their existence on being known. His answer is "no."

${ }^{61}$ James depicts acquaintance as an all-or-nothing affair in his posthumously published work, Some Problems of Philosophy of 1911: "Your acquaintance with reality," he says, "grows literally by buds or drops of perception, [which] ... come totally or not at all” (155). We know Russell to have been reading this work during the composition of POP (see Russell's letter to Ottoline Morrell of July 17 [Papers, 6:290], where he mentions that he is reading a posthumous work by James. The work in question cannot have been James's, Memories and Studies, for it did not appear until August 1911.) ${ }^{62}$ Caution on this point is necessary for two reasons. First, there is the obvious fact that, since Russell frequently changes his mind, it would be rash to assume that a position stated just once was in place years before—or, indeed, years afterward. Second, in his "Reply to Hugh McColl" of 1904 Russell speaks of acquaintance as if it entailed a recognitional capacity. He says: "We may be 
acquainted with Jones so as to know him when we meet him, and yet we may know nothing about his bank account" (Papers 4: 483; emphasis added). If, as this remark suggests, acquaintance entails a recognitional capacity, it should be gradable, since the ability to recognize something varies from person to person and from context to context. I may, for instance, be better at recognizing Pinot Noir once I have tasted many of them, and I am certainly worse at doing so than a wine expert.

${ }^{63}$ I take a maximal constituent to be a constituent that is a part of no other constituent.

${ }^{64}$ See Proops, "Russell on Substitutivity," for such a view.

${ }^{65}$ In his 1905 paper “The Nature of Truth,” for example, he appeals to primitive modality in characterizing propositions as “possible objects of belief” (Papers, 4:495).

${ }^{66}$ Tye, Consciousness Revisited, 97.

${ }^{67}$ Russell read Appearance and Reality in 1894 and reread it in 1897 (Papers, 1:353, 359).

${ }^{68}$ Bradley, Appearance and Reality, 359; emphasis added.

${ }^{69}$ For remarks that would at least seem to suggest that these terms are applicable to Bradley's absolute, see Bradley, Appearance and Reality, 468 and 542. And for an example of a philosopher who holds that "perfect" and "finished" are terms that characterize Bradley's Absolute, see E. D. Fawcett, “Ground of Appearances,” 207. Finally, compare Harold Joachim, “'Absolute’ and 'Relative' Truth," 5, for examples of similarly Bradlean uses of the terms "complete," "perfect" and "full."

${ }^{70}$ Compare Bradley's claim that "Nothing is perfect as such." Appearance and Reality, 487.

${ }^{71}$ I am grateful to Michael Kremer for drawing this remark to my attention.

72 The "axiom" also has a weaker reading, according to which all relations are merely grounded in the natures of their terms; but the stronger reading seems to be the one present in the present argument. (For Russell's own recognition of the two possible readings, see Russell, "On the Nature of Truth," 38.) 
${ }^{73}$ One suspects that Russell felt entitled to assemble a composite photograph of his target argument simply because the view for which it argued was so widely held. William James, in an essay published in the Atlantic Monthly in 1880 and reprinted in his Will to Believe, 1897, describes the view that "a complete acquaintance with any one thing, however small, would require a knowledge of the entire universe" as a "common platitude" (James, Will to Believe, 163).

${ }^{74}$ Since James here speaks of "an exhaustive acquaintance with a thing" as if it required a comprehensive body of knowledge about that thing, it seems that in 1882 he had either not yet drawn the distinction between acquaintance and knowledge-about — a distinction he would come to draw in “On the Function of Cognition" $(1885,31)$ and in the Principles of Psychology—or he was not yet using 'acquaintance' as a technical term.

${ }^{75}$ As Stewart Candlish observes (Russell/Bradley Dispute, 8), the habit was not a good one because in his work, The Principles of Logic, Bradley expressly repudiates the label "Hegelian” (preface, x).

${ }^{76}$ According to the Oxford English Dictionary, the word "quite" occurs in British English both as an intensifying adverb and as a moderating one, and is itself capable of modifying adverbs of manner. Accordingly, one may wonder whether "quite fully" might here mean nothing stronger than "rather fully." Russell, however, rarely uses "quite" except as an intensifier- that is, as meaning "absolutely" (compare, for example, POP 14, 18, 116) —and the context suggests that it has that meaning here.

${ }^{77}$ Here is another instance of Russell's equation of "knowledge of what $x$ is" with "acquaintance with $x . "$

${ }^{78}$ Some evidence that Joachim may be included—no doubt together with Bradley—among Russell's intended targets in POP is the fact that the former, in the course of expounding his idealist views on knowledge and inquiry, employs adjectives corresponding to each of the adverbs—_completely,' 'fully,' and 'perfectly' - that Russell employs when describing how we know a sense-datum (Joachim, Nature of Truth, 101). 
${ }^{79}$ Donovan Wishon notes (in conversation) that Russell's use of the Independence Thesis in the endeavor to expose the Monistic Idealist's error in supposing that perfect acquaintance requires knowledge of all the truths about a thing is also present in OKEW (151) — a point that should help to allay any concerns one might have about the temporal distance between Russell's 1918 and 1911 discussions.

${ }^{80}$ I owe this observation to James Levine.

${ }^{81}$ Dickens, Tale of Two Cities, 98.

${ }^{82}$ Whately, Life and Correspondence, 346 cited in Oxford English Dictionary, $2^{\text {nd }}$ ed. 1989: "Being sure of his being better acquainted than most people in England of the real state of Irish affairs."

${ }^{83}$ Bradley offers no more precise ground for this thesis than that "Truth is one aspect of experience, and is therefore made imperfect and limited by what it fails to include" (Appearance and Reality, 545). ${ }^{84}$ James cites Alexander Bain as raising such a doubt (Principles of Psychology, 2:6n*), but here he offers merely a dogmatic response. For more recent raisings of the doubt see Wilfrid Sellars, Empiricism; David Pears "Function of Acquaintance," and Tim Crane "Tye on Acquaintance," which is discussed below.

${ }^{85}$ Crane, "Tye on Acquaintance."

${ }^{86}$ Tye, "Reply to Crane."

${ }^{87}$ My thanks for comments on earlier drafts and/or conversation to: Rachel Abrams, Karen Carroll, Katherine Dunlop, Michael Kremer, Michael Potter, Mark Sainsbury, Nicole Smith, Craige Roberts, Nathan Salmon, Peter Sullivan, and Michael Tye. Special thanks to Fatema Amijee, Alex Grzankowski, Nicholas Griffin, Jim Levine, and Donovan Wishon, each of whom gave generous and detailed comments on one or more drafts of this article. Special thanks also to Peter Hylton for insightful criticisms that led to substantive changes. I am grateful to two anonymous referees for the journal. The paper was presented at Princeton University and at conferences held at The University 
of Texas at Austin, The University of Mississippi, and The University of Indiana, Bloomington. Parts of it were also presented at a session of the Society for the Study of the History of Analytic Philosophy at the 2012 Central Division meetings of the APA in New Orleans and at the Orange Beach Epistemology Conference, Alabama, 2013. I am most grateful to the audiences on each of those occasions for their helpful comments and criticisms. Part of this article was written while I was the GlaxoSmithKlein Fellow at the National Humanities Center, Research Triangle Park, North Carolina. I am grateful to the Center and its staff for the extraordinarily supportive intellectual environment it created in the nine happy months I spent there and to GlaxoSmithKlein for funding the Fellowship. My thanks to the University of Texas at Austin for its generous supplemental funding during this period. Finally, I should like to thank the Harry Ransom Center at The University of Austin at Texas and the heirs of the Bertrand Russell Estate for permission to quote material from the Lady Ottoline Morrell archive. 